Ankara Üniversitesi Türk Inkılâp Tarihi Enstitüsü Atatürk Yolu Dergisi

S 25-26, Mayı-Kasım 2000 s. 73-117

\title{
Damat Ferit Paşaya Karşı Düzenlenen Bir Suikast Girişimi -Nedeni ve Sonuçları-
}

\author{
Yrd. Doç. Dr. Osman AKANDERE* \\ $\ddot{O Z Z}$
}

Millî Mücadele'ye karşı olmalartyla bilinen Damat Ferit Paşa ile Ali Kemal ve Sait Molla'yı hedef alan bir suikast girişimi Haziran 1920 yılında ortaya çıkarılmıştır. Bursa'daki Kuva-yı Milliye ileri gelenlerince planlanan bu suikast hareketi gerçekleştirilemeden ortaya çıkarılmıştı.

Suikast davasindan tutuklananların yargılamaları İstanbul Birinci DivanHarb-i Örfisi tarafından yapılmış ve toplam 16 idam cezası verilmişti. Tutuklu sanıklardan idama mahkum edilen 4 kişi, 12 Haziran 1920'de asılarak idam edilmişlerdir.

Suikast girişimi ile İstanbul'da gizli olarak kurulan ve Millî Mücadele'ye pek çok yardım ve hizmetleri olan Karakol Cemiyeti' de deşifre edilmiş, bu cemiyetin bir çok üyesi tutuklanmış ve cemiyet ciddi anlamda sarsıntıya uğramıştı.

Anahtar Kelimeler: Damat Ferit Paşa, Suikast Girişimi, Karakol Cemiyeti, Birinci Divan-ı Harbi Örfi, İdam.

\section{An Assasination Attempt To Damat Ferit Pasha, Its Causes and Effects}

\section{ABSTRACT}

An assassination attempt which target Damat Ferit Pasha, Ali Kemal and Sait Molla who were known to be against the National Struggle was revealed in June 1920. Planed by the leaders of National Forces in Bursa, assassination had been revealed before it was realised.

'Selçuk Üniversitesi Teknik Bilimler Meslek Yüksekokulu Atatürk İnkılâpları ve Türkiye Cumhuriyeti Tarihi Dersi Öğretim Üyesi. 
They where taken to court and their trials were on Istanbul (primary) Military Court and six teen death sentence were given. Four of those who were under arrest where hanged.

Thanks to the assassination attempt, Karakol Organisation secretly established in Istanbul and helped National Struggle a lot was deciphered, mast of its members were arrested and the organisation was, really undermined.

Key Words: Damat Ferit Pasha, An Assassination Attempt, Karakol Organisation, (Primary) Military Court,

\section{GİRIŞ}

1920 yılı Haziran ayının ilk günlerinde İstanbul gazetelerinde çıkan bir haberin başlıkları oldukça dikkat çekiciydi. Gazetelerin birinci sayfalarında yer alan bu haberde; Damat Ferit Paşa ile bazı şahıslar hakkında bir suikast girişiminin ortaya çıkarıldığı, suikastçıların tutuklandığı, suikastın Ankara ve Bursa'daki Kuva-yı Milliye ileri gelenlerince planlandığını yazılıydı. Ayrıca suikasta yardım edecek olan Kuva-yı Milliye'nin İstanbul'daki gizli örgütünün de ortaya çıkarıldığı ve pek çok kişinin yakalandığı belirtiliyordu.

Bu dava ile ilgili duruşmalar, İstanbul Birinci İdare-i Divan-1 Harbi ya da halk arasında bilinen ismiyle (Nemrut) Mustafa Paşa Divan-1 Harb-i Örfiye'nce üç duruşmada ve birkaç gün içinde sonuçlandırılmıştı. Bu davadan yargılananlardan 16 kişiye idam cezası verilmiş, diğer sanıklar ise değişik cezalar almışlardı. İdam cezası alan dört kişi mahkeme kararının Padişah tarafından onaylanmasının ertesi günü, 12 Haziran 1920'de Beyazıt Meydanında asılarak idam edilmişlerdi.

Yargılamalar sırasında suikastçıların birbirleri aleyhinde açıklamalarda bulunarak, Kuva-yı Milliye'ye yardımcı olan İstanbul'daki askerî ve sivil bazı şahısların isimlerini ortaya çıkaran listeler verdikleri, hem gazetelerde, hem de Divan-1 Harb-i Örfi'nin gerekçeli kararında yer almıştı. Yargılama sürecinde mahkeme, davayı iki ayrı yapıda ele almış ve tutuklananların bir kısmı suikast girişiminden, diğer bir kısmı da İstanbul'da geniş bir gizli teşkilât oluşturarak Kuva-yı Milliye'nin “amal ve gayesine” hizmet etmek suçundan yargılanmışlardı.

İstanbul'daki gizli "Karakol" cemiyetinin bir çok mensubunun isminin de yer aldığı bu yargılamalar sonucunda, söz konusu cemiyetin yapısı da sarsıntıya uğramış ve faaliyetleri durma noktasına gelmişti.

İşte Damat Ferit Paşa Hükûmeti ve bazı muhalif çevrelerce Kuva-yı Milliye Hareketi ve bu hareketin Ankara ve Bursa'daki ileri gelenleri aleyhinde aleyhte bir propagandaya dönüştürülen bu "suikast girişiminin"; nedeni, planlayıcıları, tetikçileri, suikast girişiminin ortaya çıkarılması, 
tutuklama ve yargılama süreci ile bu suikastın ortaya çıkardığı sonuçlar çalışmamızın ele alacağı konular olacaktır.

\section{SUIKAAST GIRIŞIMININ HEDEF ALDIĞI KİŞİLER VE NEDENLERI}

Suikast girişimi üç kişiyi hedef almıştı. Bunlar; o günlerde dördüncü defa Sadrazamlık makamında bulunan Damat Ferit Paşa ${ }^{1}$, eski Maarif ve Dahiliye Nazırı ve Peyam-1 Sabah gazetesi baş yazarı Ali Kemal ${ }^{2}$ ile Adliye Nezâreti Müsteşarı ve İngiliz Muhibleri Cemiyeti'nin kurucusu Sait Molla idi ${ }^{3}$. Suikast girişiminin basının gündemine geldiği ilk günlerde bu üç isme ilave olarak eski Dahiliye Nazırlarından Mehmet Ali Beyin ismi gazete haberlerinde yer almışsa da ${ }^{4}$ Divan-1 Harbin gerekçeli kararında ve Takvim- $i$ Vekâyi'de yayınlanan İrade-i Seniyyede Mehmet Ali Beyin ismi yoktur. ${ }^{5}$. Dolayısıyla suikast girişiminin hedefi Damat Ferit Paşa, Ali Kemal ve Sait Molla'dır. ${ }^{6}$

'Mütareke Dönemi olarak adlandırılan 1918-1922 yılları arasında beş defa hükûmeti kurmakla görevlendirilmiş bulunan Damat Ferit Paşanın görevde kaldığı süreler şöyledir:

1. Damat Ferit Paşa Hükûmeti : (4 Mart-15-16 Mayıs 1919)

2. Damat Ferit Paşa Hükûmeti . (19 Mayıs- 20 Temmuz 1919)

3. Damat Ferit Paşa Hükûmeti : (2I Temmuz- I Ekim 1919)

4. Damat Ferit Paşa Hükûmeti : (5 Nisan-31 Temmuz. 1920)

5. Damat Ferit Paşa Hükûmeti : (31 Temmuz-17 Ekim 1920 .

Bu bilgi için bkz. Nazım Tektaş, Sadrâzamlar-Osmanlı'da Ikinci Adam Saltanatı, Çatı Kitapları, İstanbul 2002, s.718-730.. Damat Ferit Paşa ile Hükûmetleri konusunda yapılmış ayrıntılı bir araştırma için bkz. Ş. Can Erdem, Damat Ferit Paşa, Marmara Üniversitesi Sosyal Bilimler Enstitüsü, Basılmamıș Doktora Tezi, , İstanbul 2002.

${ }^{2}$ Ali Kemal, Damat Ferit Paşanın 4 Mart 1919'da kurduğu birinci Hükûmeti'nde Maarif Nazırlığı görevine getirilmiş, Damat Ferit Paşanın 19 Mayıs 1919'da kurduğu ikinci Hükûmetinde ise Dahiliye Nazırlığı görevinde bulunmuştu. Bkz. Osman Özsoy, Gazetecinin Infazı Timaş Yay. İstanbul 1997, s.104-105 ve 107.

${ }^{3}$ Ingiliz Muhipleri Cemiyeti'nin kurucularından olan Sait Molla, İngilizler lehinde ve İngiliz mandasının kabul edilmesi yönünde yazdığı makalelerle dikkat çekmiştir. Sait Molla, Şûrâ-yı Devlet üyeliği ve Adliye Nezareti Müsteşarlığı yapmış, İngilizlerden aldığı parayla "Türkçe İstanbul" gazetesini çıkarmıștır. Sait Molla aynı zamanda İngiliz Büyükelçiliği'nden ayda 300 lira alan bir İngiliz ajanıydı. Bu bilgi için bkz Cengiz Dönmez, Millî Mücadele'ye Karşı Bir Cemiyet: Íngiliz Muhibleri Cemiyeti, Atatürk Araştırma Merkezi Yay. Ankara 1999, s.63, Dipnot: 234 .

${ }^{4}$ Alemdar, 2 Haziran 1336(1920), Nr: 529/2829.

${ }^{5}$ Dramalı Rıza Bey ile arkadaşları hakkında verilen idâm kararının gerekçeli kararında yer alan bu bilgi için bkz. Başbakanlık Osmanlı Arşivi(BOA), Dosya Usulü İradeler Tasnifi (DUiT), Nr.79/5-117. Belge için bkz. EK. I; Takvim-i Vekâyi, 12 Haziran 1336(1920), Nr.3878. Ayrica bkz. Vakit, 13 Haziran 1336/1920), Nr.918; Alemdar, 13 Haziran 1336(1920), Nr.540/2840; Peyam-l sabah, 13 Haziran 1336(1920), Nr.556/10986.

${ }^{6}$ BOA, DUIT, Nr.79/5-117; Alemdar, 1 Haziran 1336(1920), Nr: 528-2828.; Alemdar, 2 Haziran 1336(1920), Nr.529/2829. Peyam-l sabah, 2 Haziran 1336(1920), Nr.545/10975; Vakit, 2 Haziran 1336(1920), Nr.906. 
Suikast girişiminin hedef aldığı bu üç ismin gelişigüzel belirlenmiş kişiler olmadığı hemen görülecektir. Bunlar Kuva-yı Milliye hareketine aşırı düşmanlık gösteren kişilerdir. Üçünün de ortak noktası şiddetli Millî Mücadele aleyhtarlığı idi. Damat Ferit Paşa kendi iktidarlarındaki siyaset ve uygulamalarıyla, Ali Kemal Peyam-ı Sabah gazetesindeki köşesinde yazdığı "zehir zemberek" yazılarıyla ve Sait Molla ise İngilizlerle yaptığı işbirlikçi tertip ve düzenleriyle tanınmaktaydılar. Bu isimler aynı zamanda Mütareke günlerinde, İstanbul'un politik, siyasî ve askerî yapısı üzerinde de oldukça etkiliydiler. İngiliz himayeciliğinin de şiddetli taraftarı olan bu üç isim, İngilizlerin İstanbul'daki en güvenilir gördüğü kişilerdi denilebilir ${ }^{7}$.

Millî Mücadele aleyhtarlığı ile tanınan bu üç isim hakkında zaman zaman Millî Mücadele ileri gelenlerince bazı tepkiler ve hatta yaptırımlar söz konusu edilmiştir. Nitekim Sivas Kongresi'nden sonra Damat Ferit Hükûmeti'nin iş başından uzaklaştırılması için girişilen çabalar ve bu çerçevede Sadrazam Damat Ferit Paşaya ${ }^{8}$ ve Padişaha gönderilen telgraflar örneğinde olduğu gibi ${ }^{9}$. Yine Anadolu ve Rumeli Müdafaa-i Hukuk Cemiyeti Heyet-i Temsiliyesi adına Mustafa Kemal Paşa, iş başına geldiği günlerde Sadrazam Ali Rıza Paşaya çektiği telgrafında, eski nazırlardan Ali Kemal'in de aralarında bulunduğu bazı kişilerin "Divan-ı Âli'ye" verilmesini istemişti. ${ }^{10}$

\footnotetext{
${ }^{7}$ Mütarekeden sonra 20 Mayıs 1919'da İ́stanbul'da kurulan ve İngiliz mandaterliğini esas almış olan "Íngiliz Muhibleri Cemiyeti'nin kurucusu Sait Molla'ydı. Padişah Mehmet Vahdettin ile Sadrazam Damat Ferit Paşanın cemiyetin resmî üyesi olup olmadıkları konusunda açık bir bilgi olmamakla beraber, cemiyete bağlılıklarının bulunduğu ve cemiyete destek verdikleri aşikardı. Bu cemiyeti ele aldığı çalışmasında Cengiz Dönmez "Bu çerçevede, Millî Harekete karşı işgal kuvvetleriyle işbirliği yaparak, bu harekete zarar verebilmek için her türlü yolu denemekten geri kalmayan Damat Ferit Paşa'dan başka, o dönem hükümetlerinde görev almış, Dahiliye ve Maarif Nazırlarından Ali Kemal ile Dahiliye Nazırlarından Mehmet Ali ve Adil Beyler de cemiyetle, hem organik bağları olan, hem de yürüttükleri Millî Mücadele aleyhindeki faaliyetler sebebiyle, yakın ilişki içerisinde bulunan hükümet üyeleri olmuşlardır" demektedir. Bkz. Dönmez, a.g.e., s.128.

${ }^{8}$ Sivas Kongresi Heyeti adına Damat Ferit'e çekilen telgrafta, kendisine ve hükümetine milletin güveni kalmadığı belirtilerek, derhal hükûmetten ayrılması istenmişti. "Aksi takdirde bütün vatanın meşru olmayan bu hükûmetle bağlantısını keseceği” belirtilmişti. Bu telgrafın tamamı için bkz. M. Kemal Atatürk, Nutuk, C.1 (1919-1920), Yay. Haz. Zeynep Korkmaz, Başbakanlık Basımevi, Ankara 1984, s.96-97.

${ }^{9}$ Sivas Kongresi Heyeti adına Mustafa Kemal Paşa tarafından Padişaha gönderilen telgrafla, Damat Feri Paşa Hükûmeti'nin Dahiliye ve Harbiye Nazırları vasıtasıyla bir plan çerçevesinde Elazığ valisi Ali Galip ve bazı Kürt aşiretlerinin işbirliği ile Sivas Kongresi'nin basılması tertibine girdikleri belirtilerek, "bu hükûmete olan güven ve itimadın zedelendiği ve bir an önce adaletli yeni bir hükûmetin iş başına getirilmesi” istenmişti Bu telgraf için bkz. M. Kemal Atatürk, Nutuk, C.III (1919-1927) Belgeler, Yay. Haz. İsmet Gönülal, Başbakanlık Basımevi, Ankara 1984, s.48-49, Belge No: 82.

${ }^{10} \mathrm{Bu}$ telgrafında Mustafa Kemal Paşa, yeni hükûmetin kendilerinden açıklanmasını istediği hususlarda bilgi vermiş ve sonra da yeni yerine getirmesi için öngörülen teklifleri sıralamıştı. Bu tekliflerin dördüncü maddesinde "Eski nazırlardan Ali Kemal ve Adil Beylerle
} 
Ayrıca Türkiye Büyük Millet Meclisi, 20 Mayıs 1920'de Damat Ferit Paşanın vatan haini olduğuna dair kanunu görüşerek kabul etmişti. Bu kanunla Damat Ferit Paşa "vatandaşlık hukukundan tecrit edilerek" Türk vatandaşlığından çıkarılmıştı". Damat Ferit Paşa, Ali Kemal ve Sait Mola ve bazı Millî Mücadele aleyhtarları hakkında 3 Temmuz 1920 tarihinde "Ankara Merkez Bidayet Mahkemesi Ceza Dairesi" tarafından giyaplarında yapılan yargılama sonucunda "idam" cezası verilmişti' ${ }^{12}$. Damat Ferit Paşa, Sevr Antlaşmasını kabul ederek imzalaması üzerine de Ankara I. İstiklâl Mahkemesi'nin bir numaralı kararı ile gıyabında tekrar idama mahkum edilmişti ${ }^{13}$.

Tekrar suikast girişimine dönecek olursak, Divan-1 Harb-i Örfi'nin bu davaya ilişkin verdiği gerekçeli kararda suikastın biri görünürde, diğeri de gizli olmak üzere iki nedene dayandığı belirtiliyordu. Suikastın görünürdeki nedeni, İtilâf Devletleri ile sürdürülen sulh antlaşmasının yani Sevr Antlaşması'nın, Damat Ferit Paşa Hükûmeti'nce kabul ve imza edilmesine mani olmakt ${ }^{14}$. Gerekçeli kararda suikastın gerçek nedeni konusunda ise, Kuva-yı Milliye ileri gelenleri ve onların "âmal ve gayelerine" hizmet eden bazı millî teşkilât mensupları İstanbul'da bir ihtilâl yapmayı planlamışlardı. Böylece hükûmetçe haklarında yapılan kovuşturma ve takiplerden kurtulacaklar ve asîlik hareketlerine rahatça devam edeceklerdi. Bu ihtilâl hareketi ile mevcut Damat Ferit Paşa Hükûmeti iş başından uzaklaştırılacaktı $\mathrm{Bu}$ hükûmetin yerine kendi emel ve gayelerine hizmet edecek yeni bir hükûmeti iktidar mevkiine getireceklerdi. Bu tasavvurları önünde en büyük engel olarak görülen Damat Ferit Paşa, Ali Kemal ve Sait Molla Beyler katledilmeliydi ${ }^{15}$. Bunların katledilmesi de onlara yönelik olarak girişilecek bir suikast ile mümkün olacaktı.

Süleyman Şefik Paşa'nın Meclis açıldığında Yüce Divan'a(Divan-ı Âli'ye) verilmek üzere, hiçbir yere kaçmalarına meydan verilmemesini ve özellikle Posta ve Telgraf Genel Müdürü Refik Halit Beyin hemen tutuklanarak ilgili mahkemeye verilmesini, kanunun üstünlüğü ve milli hakların kutsallığı adına isteriz" denilmekteydi. Bkz. Nutuk, C.I, s. 136 ve Nutuk, C.III, s.103-105, Belge No: 132.

${ }^{11}$ Bu kanunun Türkiye Büyük Millet meclisindeki görüşmeleri için bkz. Türkiye Büyük Millet Meclisi Zabıt Ceridesi, Devre.1, C.1, s.343; Bu kanunun ülkeye duyurulması hakkındaki tamim için de bkz. Atatürk'ün Tamim, Telgraf ve Beyannameleri, IV, Atatürk Araştırma Merkezi Yayını, Ankara 1991, s.347, Belge No: 334.

${ }^{12}$ Bu idam kararı için bkz. Opr. Dr.Cemil(Paşa) Topuzlu İstanbul Eski Şehremini, Istibdat-Meşrutiyet-Cumhuriyet Devirlerinde 80 Yıllık Hatıralarım, Haz. Cemalettin Topuzlu, 4. bs., İstanbul 2002, s.205-206.

${ }^{13}$ Ankara I. İstiklâl Mahkemesi bir numaralı Kararı ile "Sadrazam Ferit, Ayândan Hadi, Rıza Tevfik, Bern Sefiri Reşat Halis" haklarında "Hıyanet-i Vataniye Kanunu'nun 1. ve 2. Maddelerine uygun olarak gıyaplarında idam cezası vermişti. Bkz. İhsan Ezherli,, Türkiye Büyük Millet Meclisi (1920-1998) ve Osmanlı Meclis-i Mebusanı (1877-1920), 2. Baskı(Genişletilmiş), TBMM Kültür, Sanat ve Yayın. Kururlu Yay., Ankara 1978, s.70.

${ }^{14}$ BOA, DUIT, Nr.79/5-117.

${ }^{15}$ BOA, DUIT, Nr.79/5-117. 
Suikastın nedeni konusunda 1 Haziran 1920 tarihli Alemdar gazetesi "Suikast Mürettiplerinin Tevkifi” başlıklı haberinde şunlar yazılıyordu:

"Ülkenin geçirmekte olduğu buhrân-1 müdhiş vazıyeti asla nazar-1 dikkate almayarak, mevki-i iktidâra suûd edebilmek içün Anadolu'da yaptığı gibi İstanbul'da da tedhîş siyâsetini takibden fariğ olmayan Ankara serserileri âmal ve niyet-i ihtiraspervârânelerine en mühim bir manî telakki eyledikleri Sadrazam Damad Ferid Paşa Hazretlerine karşı bir suikasd tertîb eylemişler ve bu fikr-i cinâyet-kârâneyi icrâya en azılı iki fedailerini me'mur eylemişlerdir" ${ }^{\prime \prime}$

Refi Cevat da "Suikast Hakkında" başlıklı yazısında "Sadrazam Damat Ferit Paşa gibi bir rical-i hükûmete suikast tertip edilmek suretiyle, memleketin muhtaç olduğu sükûn ve sükûnetin ihlal edilmek istendiğini" belirterek, suikastçıların bu suretle ortalığı karıştırmak, huzur ve asayişi bozmak istediklerine dikkat çekmekteydi ${ }^{17}$.

Gerçekten de suikastın amacı Damat Ferit Paşayı ortadan kaldırmaktı. Sonraki bölümlerde açıklayacağımız gibi, bu suikastın planlanmasında önemli rol sahibi olan kişilerin başında Hacim Muhittin (Çarıklı) Bey geliyordu. Hacim Muhittin Bey hatıralarında amaçlarının "Damat Ferit'i bertaraf etmek olduğunu" belirtmektedir ${ }^{18}$. Damat Ferit paşaya yönelik bu suikast fikrinin kendisinden çıktığını ve hatta Dramalı Rıza Beyi bu işe kendisinin azmettirdiğini söyleyen Çerkes Ethem ise suikastın amacını şöyle açıklamaktaydı: "Bu menhus ve tıynetsiz adamı öldürtmek ve böylece onun yolunda yürüyecek olanlara da ibret teşkil edecek bir tedip numunesi vermek lâzım geliyordu"19

Görüleceği gibi suikastın amacı Damat Ferit Paşayı öldürerek, İstanbul'da iktidar mevkiinde bulunan ve bulunacak olanlara bir gözdağ 1 vererek, bunlarca Kuva-yı Milliye hareketine ve bu hareket içinde yer alan sivil ve askerî şahsiyetlere karşı yürütülen düşmanca politika ve uygulamalar sona erdirilecekti. Ali Kemal'in şahsında da ise Kuva-yı Milliye aleyhinde olan gazete ve gazetecilerin halkı ve dolayısıyla kamuoyunu Kuva-yı Milliye aleyhine tahrik ve teşvik etmelerinin önü alınacak, muhalif basın susturulmaya çalışılacaktı. Sait Molla'nın öldürülmesi ile de Mütareke Dönemi'nde başta İngilizler olmak üzere Fransız ve Yunanlılarla işbirliği yapan ve bu işbirliklerini vatan hainliği noktasına kadar götüren siyasî parti, cemiyet ve kişiler uyarılacaktı.

\footnotetext{
${ }^{16}$ Alemdar, 1 Haziran 1336(1920), Nr. 528/2828.

${ }^{17}$ Refi Cevat, "Suikast Hakkinda", Alemdar, 3 Haziran 1336(1920), Nr. 530/2830.

${ }_{18}$ Balıkesir ve Alaşehir Kongreleri ve Hacim Muhittin Çarıklı'nın Kuvayı Milliye Hatıraları 1919-1920, Yay. Haz. Şerafettin Turan, Türk İnkılâp Tarihi Enstitüsü Yay., Ankara 1967, s.110.

${ }^{19}$ Cemal Kutay, Çerkes Etkem Hadisesi (Kendi Hatıralartyla), Tarih Kütüphanesi Yay., İstanbul 1955, s.18.
} 
Suikast ile ulaşılmak istenen bir diğer amaç da, mevcut hükûmetin düşürülmesi sağlanarak yerine Ali Rıza Paşa ve Salih Paşa Hükûmetleri gibi, açıktan olmasa bile gizli ve dolaylı yollardan Kuva-yı Milliye'ye yardımcı olacak bir hükûmeti iktidar mevkiine taşımaktı.

\section{SUIKASTIN PLANLANMASI}

Damat Ferit Paşaya düzenlenecek suikast girişimini planlanması ile ilgili olarak da bazı farklı yaklaşımlar ve anlatımlar mevcuttur.

Suikast girişimi ile ilgili gazetelerde çıkan haberlere göre, bu iş Ankara'da planlanmış, ancak ayrıntılar ve gerekli hazırlıklar Bursa'daki Kuva-yı Milliye ileri gelenlerince yapılmıştı. Ayrıca, suikastı gerçekleştirecek olanlar ile onlara bu işte yardımcı olacak kişiler Bursa'dan gönderilmişti. Bu suikast girişimi öncesi ve sonrası, bu işi yapacak olanlara yardımcı olacak İstanbul'daki gizli teşkilât mensupları hep Bursa ile yazışma yapmışlardi $1^{20}$.

Suikast ile ilgili basına bilgi veren İstanbul Polis Müdüriyet-i Umumîsi Hasan Tahsin Bey, suikast girişiminden "Bursa'ya gönderilen bir mektup sayesinde haberdar olunduğu ve bütün Kuva-yı Milliye ileri gelenlerinin olayın içinde bulunduklarını" söylemekteydi ${ }^{21}$.

Suikast sanıklarını yargılayan Divan-ı Harb-i Örfisi'nce tanzim edilen "mazbata-i hükmiye" de ise suikastın Bursa kaynaklı oluşu daha ilk cümlelerde belirtilmekte ve şöyle denilmekteydi:

\footnotetext{
"Sadrazam Damad Ferid Paşa Hazretleri ile Dahiliye Nazır-ı esbakı Ali Kemal ve Adliye Müsteșarı Sait Molla Beylere suikast teşebbüsünde ve vasî teşkilât-ı hafiyede bulundukları beyânıyla maznûn-ı aleyhim olan Bursa'da 56. Fırka Kumandanı Bandırmalt Bekir Sami Bey(...) ve Karesi(Balıkesir) mutasarrıf-ı sabıkı olub Kuva-yı Milliye nâmı altında müteşekkil fitne-i bagiye tarafından Bursa vilâyeti valiliğine tayin edilmiş olan(...) Hacim Bey ve Üsküdar Jandarma Taburu Kumandanı olub ahîren firar ile Bursa'ya giderek usât-ı merkûmeye iltihâk ve Bursa Jandarma Kumandanlığını ifa etmekte olan(...) Manastırlı Remzi Bey(...)ve kezalik bugât-ı merkûmenin Bursa Polis Müdiriyetini ifâ etmekte olan Nuri Efendi..."22
}

20 1 Haziran 1920 tarihli Alemdar gazetesinde çıkan "Suikast Mürettiplerinin Tevkifi" başlıklı haberde:

"Ankara'da tertip edilen bu harekâtı cinayet-karânenin teferruatı Bursa'da tanzim olunuyor. Gerek suikastı icra edecek olan failler, gerek onların bu harekâtını teshîl ve ifhâm eyleyecek olanlar, muînler, müşevvikler hep orada hazırlanıyordu" denilmekteydi Alemdar, 1 Haziran 1336(1920), Nr:528/2828.

${ }^{21}$ Alemdar, 2 Haziran 1336(1920), Nr.529/2829. Peyam-l Sabah, 2 Haziran 1336(1920), Nr.545/10975; Vakit, 2 Haziran 1336(1920), Nr.906.

${ }^{22}$ BOA, DUIT, Nr.79/5-117. 
$\mathrm{Bu}$ ifadeden anlaşılacağ yapan "ordu kumandanı, valisi, jandarma kumandanı ve polis müdürü" doğrudan suikast girişiminin içindeydi ve planlayıcılarıydı. Hacim Muhittin Bey, suikastın planlanmasındaki rolü konusunda "Damat Ferit Paşayı bertaraf etmek için Dramalı Rıza'dan istifade etmeyi düşündük ve bunu kendisine teklif ettik o da memnuniyetle kabul etti. İstanbul'daki teşkilâtla (daha yakından alakası olan) arkadaşlar vasıtasıyla temas ettik. Günün birinde Rıza'yı üç kişi olarak İstanbul'a gönderdik." demektedir*.

Gerçekten de suikast davasında bu isimlerin de giyaplarında yargılandığı ve haklarında idam cezası verildiğini göz önüne aldığımızda, suikastın kesin olarak Bursa'da planlandığı anlaşılacaktır. Suikastın planlanmasında İstanbul'daki bir gizli teşkilât ile işbirliği yapıldığı da aşikardır. Bu gizli teşkilâtın adı açıç̧a belirtilmemesine rağmen, bunun Karakol Cemiyeti olduğunu biliyoruz ${ }^{23}$. Çünkü tutuklanan isimlerine bakıldığında bunların, cemiyetin İstanbul'da gizli olarak oluşturduğu semt şubelerine ${ }^{24}$ mensup kişiler olduğu görülecektir.

Nitekim suikast davasında isimleri geçen ve yargılanarak idam dahil çeşitli cezalara çarptırılan bu isimlerden Davavekili Baha Sait Bey, Karakol Cemiyeti'nin kurucularındandır. Binbaşı Tolcalı Süleyman, Binbaşı Üsküdarlı İhsan, Binbașı Kemal Beyler ise yönetim kurulu üyesiydiler ${ }^{25}$. Yüzbaşı İsmail Hakkı ve Yüzbaşı Bican Beyler Topkapı şubesinin elemanlarıydılar ${ }^{26}$. Bu davadan yargılanarak idam edilen Tevfik(Sükûti) Bey ise Karakol Cemiyeti'nin kurduğu Menzil Hattı Amirliği'nin

\footnotetext{
"Çarıklı, a.g.e., s. 110.

${ }^{23}$ Karakol Cemiyeti İstanbul'da Müdafaa-i Hukuk davasını desteklemek amacıyla kurulan ilk gizli teşkilâtlardan birisidir. Bu cemiyet Kasım 1919'da kurulmuştu. Kuruluş yeri ve merkezi İstanbul'da olup, Bâb-1-Âli caddesinde "Resne" isimli fotoğrafhane olarak kullanılan Baha Sait Beye ait yazıhanedir. İlk kurucu ve idarecileri ise; şöyleydi: Reis: Kara Vasıf Bey, Miralay Şevket, Onuncu Kafkas Fırkası Kumandanı Kaymakam Kemâleddin Sami, Kaymakam Edip, Binbaşı Ali Rıza, Mütekaid Binbaşı Baha Sait, Davâvekili Refik İsmail, Dr. Abdulhak Adnan(Adıvar) ve Erkân-1 Harb Kaymakamı Çolak Selehaddin Bey olmak üzere dokuz kişiden oluşmaktaydı. Bu bilgi için bkz. Tarık Zafer Tunaya, Türkiye'de Siyasi Partiler 1859-1952, II. Baskı(Tipkı Basım), Arba Yay., İstanbul 1952, s.520. Karakol Cemiyeti ile ilgili ayrıntılı bir araştırma için bkz. Fethi Tevetoğlu, Millî Mücadele Yıllarındaki Kuruluşlar, TTK Basımevi, Ankara, 1988, s.3-50.

${ }^{24}$ Kendisi de Karakol Cemiyeti'nin Topkapı şubesinin faal bir elemanı olan Hüsameddin Ertürk İstanbul'da ilk olarak Topkapı şubesinin kurulduğunu ve bilahare de "Şehremini, Eyüp Sultan, Kasımpaşa, Beyazıt, Aksaray, Bakırköy, Üsküdar, Kuzguncuk, Beylerbeyi, Çengelköy, Anadolu Hisarı, Beykoz, Kavak, Sarıyer, Büyükdere, Beşiktaş ve Galata" şubelerinin kurularak faaliyete geçtiğini belirtmektedir. Hüsamettin Ertürk, İki Devrin Perde Arkası, Yay. Haz. Samih Nafiz Kansu, Sebil Yay., İstanbul 1994, s.208.

${ }^{25}$ Tevetoğlu, age., s.9; İsmet Görgülü, On Ylllık Harbin Kadrosu 1912-1922( BalkanBirinci Dünya ve Ístiklâl Harbi), TTK Basımevi, Ankara 1993, s.202.

${ }^{26}$ Ertürk, age., s.209-210.
} 
yöneticilerindendi ${ }^{27}$. Diğerleri de Karakol Cemiyeti'nin diğer şubelerine mensuptular.

Diğer taraftan Karakol Cemiyeti'nin İstanbul'un dışında faaliyetlerini en rahat şekilde sürdürdüğü vilayet Bursa'ydı. Bunun nedeni ise Bekir Sami ve Hacim Muhittin Beyler gibi askerî ve sivil yöneticilerinin teşkilâtın mensubu olmalarıydı $^{28}$. İşte bu nedenle suikastın planlanması Bursa'daki Kuva-yı Milliye ileri gelenleri ve onlarla yakından temas halinde olan İstanbul'daki Karakol Cemiyeti mensuplarının işbirliği ile yapılmıştı.

Yukarıda da belirttiğimiz gibi Çerkes Ethem, suikast fikrinin kendisine ait olduğunu söylemektedir. Çerkes Ethem'e göre, Damat Ferit Paşanın öldürülmesi, İstanbul'da onun gibi düşünen ve onun yolunda yürüyeceklere bir ders olacak ve artık açıktan açığa Millî Mücadele'ye karşı çıkamayacaklardı. Bunun için "itimat ettiği zevat" ile görüşmüş ve onlar da bu girişimi onaylamışlardı. Dramalı Rıza Beyi de suikast yapması için İstanbul'a kendisi göndermişti. ${ }^{29}$ Ancak bu anlatılanlara Hacım Muhittin Bey katılmaz ve "henüz dün denilecek kadar yakın bir tarih hadisesinin tarihe bu kadar yanlış aksettirilmesine acı acı güldüm(...) Bu tamamıyla yanlıştır. Ve Edhem bunu doğru söylememiştir" diyerek Çerkes Ethem'in bu meseleyi kendine göre halletmek istediğini belirtir. Çarıklı'ya göre ne Çerkes Edhem'in ne de hatıralarında suikast girişimini görüştüğünü ve onaylarını aldığını söylediği kişilerin hiçbir şekilde bundan haberleri olmamıştır ${ }^{30}$.

Suikastın 61.Tümen Kumandanı Kazım Beyin(Özalp) onayı ile Dramalı Rıza Bey tarafından gerçekleştirildiği şeklinde bazı anlatımlar da vardır. Bu anlatımlardan birisinde, Kazım Beyin Dramalı Rıza Beyi İstanbul'a gizli bir görev için gönderdiği belirtilerek, bu gizli görevin "Damat Ferit Paşaya suikast düzenlemek olduğu işaret edilin ${ }^{31}$. Zühtü Güven de Anzavur İsyanı isimli kitabında benzer bir anlatımla Yenice olayından sonra Balıkesir'e giden Dramalı Rıza'nın olayı ve neden dolayı cephaneliği ateşe vermiş olduğunu Kazım Beye anlattı̆̆ını belirtmekte ve devamla Tümen komutanının (Kazım Bey) cephaneliğin ateşlenmiş olmasına çok kızdığını ve işi Rıza Beyi idam ettirmeye kadar götürdüğünü söylemektedir. Güven'e göre Rıza Bey idamdan kurtulmak için Tümen komutanına, "hatasını telafi

\footnotetext{
${ }^{27}$ Mesut Aydın, Millî Mücadele Dönemi'nde TBMM Hükümeti Tarafindan İstanbul'da Kurulan Gizli Gruplar ve Faâliyetleri, Boğaziçi Yay., İstanbul 1992, s.44.

${ }^{28}$ Nitekim teşkilâtın nizamnâme, talimatname ve beyannamelerini Bursa'ya ve buradaki mensupları vasıtasıyla da Balıkesir Bandırma bölgesine göndermişti. Karakol Cemiyeti'nin Bursa bölgesindeki faaliyetleri için bkz. Çarıklı, age., s. 13-25.

${ }^{29}$ Kutay, age., s.18-20.

${ }^{30}$ Çarıklı, age., s.110.

${ }^{31}$ Zeynel Kozanoğolu kitabında şu ifadelerle bu olayı anlatmaktadır: "Dramalı Rıza Bey, o korkusuz ve kahraman insan Balıkesir'e dönüşünden sonra, Kazım Bey tarafından gizli bir görevle İstanbul'a gönderilecek, lakin hükûmet tarafından yakalanıp idam ettirilecektir" Zeynel Kozanoğlu Hamdi Bey ve Akbaş Baskını, Ankara 1970, s.111.
} 
etmek için kendisinin bırakılması halinde İstanbul'a giderek Damad Ferid Paşayı öldüreceğini" teklif etmişti. Kazım Bey de bu teklifi kabul etmiş ve Dramalı Rıza serbest bırakılmıștı. Serbest bırakılan Dramalı Rıza da Damat Ferit Paşaya suikast düzenlemek için İstanbul'a gitmişti ${ }^{32}$

Ancak, bütün bu eserlerde ifade edildiği gibi, Dramalı Rıza Bey suikastı gerçekleştirmek üzere Kazım Bey tarafından gönderilmeyecektir. Zaten Kazım Bey hatıralarında böyle bir gönderme olayından hiç bahsetmediği gibi, Dramalı Rızanın hatasını anladığından dolayı hiç karşısına çıkmadığını, bu olaydan çok üzüldügünü ve o nedenle buralarda (Balıkesir) kalamayıp, Bursa taraflarına gittiğini haber aldığını söylemektedir ${ }^{33}$

Suikast sanıklarının soruşturulması esnasında bu olayın Ankara'da Millî Mücadele önderlerinin bilgisi dahilinde planlandığına ilişkin gazetelerde haberler çıkmıştı. ${ }^{34}$. Hatta Vakit ve Peyam-ı Sabah gibi gazetelerde "Suikastın Mustafa Kemal ve Bursa'da bulunan Ali Fuat Paşa tarafindan tertip edildiği, Mustafa Kemal'in Dramall Rıza ve Halil İbrahim'i Ankara'da kabul ederek onları teşvik ettiği, bunun bir vatan hizmeti olduğunu söylediği ve onlara kendi tabancasını verdiği ve yine suikastçılara beşer bin lira mükafat vaat ettiğ $i$ " şeklinde bilgiler yer almışt ${ }^{35}$.

Ancak Ankara'nın ve dolayısıyla Mustafa Kemal Paşa ve diğer Millî Mücadele ileri gelenlerinin bu suikast hadisesini planladığı ve suikastçıları Ankara'da kabul ederek onları tahrik ettikleri ve bir takım vaatlerde bulundukları hususunda hiçbir kaynakta bir bilgiye rastlamadık. Ayrıca Dramalı Rıza Bey bu dönemde hiçbir şekilde Ankara'ya gitmemiştir. Nitekim Divan-1 Harbi Örfi'nin gerekçeli kararında da Ankara ve Mustafa Kemal Paşa ile ilgili hiçbir cümle ve ifade yer almamıştır. Bu tamamen Millî Mücadele'yi ve Mustafa Kemal Paşa başta olmak üzere bu mücadelenin ileri gelenlerini kamuoyu önünde suçlandırmak ve küçük düşürmeye matuf bir hareket olarak, İstanbul Polis Müdürlügüunün ve Alemdar ile Peyam-ı Sabah gibi Millî Mücadele aleyhtarı gazetelerin, planlı olarak ortaya attıkları bir itham ve iddiadan başka bir şey değildi.

Esasen bir çok olayı Nutuk'ta ayrıntılarıyla anlatan Mustafa Kemal, böyle bir olayda kendisinin veya o sırada Ankara'da bulunan yakın çevresinin herhangi bir rolü olmuş olsaydı, herhalde bundan bahsederdi. Ayrıca

${ }^{32}$ Zühtü Güven, Anzavur İsyanı-Kurtuluş Savaşı Hatıralarından Acı Bir Sayfa, Ankara 1965, s.51.Ayrıca bkz. İsmail Aydın Hoşgör, Kurtuluş Savaşı'nda Biga, Biga 1970, s.74.

${ }^{33}$ Kazım Özalp, Millî Mücadele I (1919-1922), 2.Basım, Türk Tarih Kurumu Basımevi, Ankara 1985, s.99.

${ }^{34}$ Alemdar, 1 Haziran 1336(1920), Nr.528/2828;

${ }^{35}$ Vakit, 3 Haziran 1336(1920), Nr.907; Peyam-t sabah, 3 Haziran 1336 (1920), Nr.546/ 10976. 
suikastın planlanmasında ismi geçmiş olan Ali Fuat Paşa da yazdığı hatıralarında bu konuyla ilgili hiçbir şeyden bahsetmemiştir ${ }^{36}$.

Diğer taraftan Mustafa Kemal Paşa, "İstanbul'daki mevcut teşkilâtımız" dediği Karakol Cemiyeti'nin tüzük ve çalışma yönergesini öğrendikten sonra, bu cemiyete karşı mesafeli olmuş, bazı faaliyetlerine sıcak bakmamışıı. ${ }^{37}$. Nitekim, Karakol Cemiyeti'nin Bursa ve civarındaki faaliyetlerinin kendisine bildirilmesi üzerine ${ }^{38}$ Mustafa Kemal Paşa; Ali Fuat Paşa, Bekir Sami ve Kazım Beylere gönderdiği telgrafında "Redd-i Ilhak, Karakol ve başka adlar altında çeşitli millî cemiyetlerin teşkilâtlanma çalışmalarını sürdüklerinden" bahsederek, Sivas Kongresi ile aynı kutsal amaç uğrunda çalışan bütün millî cemiyetlerin birleştirildiğini belirtmiş ve bu tür çalışmaların "muhtaç olduğumuz birlik ve iç düzen açısından" doğuracağı sakıncaları dile getirmişti ${ }^{39}$.

\section{SUIKASTI YAPACAK OLANLARIN BELIRLENMESI}

Damat Ferit Paşa, Ali Kemal ve Sait Molla'ya yönelik olarak planlanan bu suikast girişimini gerçekleştirecek olanlar Bursa'da belirlenmiş ve suikast için görevlendirilmişlerdi. Görevlendirilen bu suikastçılar; Dramalı Rıza Bey, Bahriye Yüzbaşısı Halil İbrahim Bey ve kimlikleri konusunda açık bilgi bulunmayan Bursa Yenişehir'den Hasan ile Bursalı çoban İsmail' $\mathrm{di}^{40}$.

Suikastı gerçekleştirmek için belirlenmiş esas kişi Dramalı Rıza Beydi. Dramalı Rıza'yı bu göreve Bursa valiliği görevini yürütmekte olan Hacim Muhittin Bey gönderecektir. Olayın seyri şöyle gelişmiştir.

Çok sevdiği ve bağlandığı Köprülülü Hamdi Beyin Biga'da şehit edilmes ${ }^{41}$, Yenice olayi ${ }^{42}$ ve bu olay esnasında kendi emrindeki vefakar ve

\footnotetext{
${ }^{36}$ Ali Fuat Cebesoy, Millî Mücadele Hatıraları, Temel Yay., İstanbul 2000.

${ }^{37}$ Mustafa Kemal Paşanın Karakol Cemiyeti'nin tüzük ve yönergesi hakkında Nutuk'ta yer alan bilgi için bkz. Nutuk, C.I, s.50-52.

${ }^{38}$ Anadolu ve Rumeli Müdafaa-i Hukuk Cemiyeti Bursa Delegesi Osman Nuri Bey çektiği telgrafta "Bursa'ya gelişimizden beri Redd-i İlhak, Karakol ve başka adlar altında aynı amaçla iş gören ve fakat türlü merkezlerden gelen bir takım teşkilâtlara rastlıyorum" diyerek Karakol Cemiyeti'nin Bursa'daki faaliyetleri hakkında Mustafa Kemal'i uyarmaktaydı. Bu telgraf için bkz. Nutuk, C.III , s.121, Belge: No:155.

${ }^{39}$ Nutuk, C. III, s. 122, Belge No: 155 .

${ }^{40}$ BOA, DUIT, Nr.79/5-117.

${ }^{41}$ İkinci Anzavur İsyanı'nın başlarında asiler tarafından Biga'da kuşatılan Köprülü Hamdi Bey Biga'da tutunamayacağını anlamıştı. Bu nedenle Dramalı Rıza Beyin bulunduğu Yenice'ye gitmek üzere yola çıkan ve durmaksızın at süren Hamdi Bey ve yanındaki birkaç adamı, dinlenmek için girdikleri İnova köyünde, Gavur İmam'ın adamlarınca tanınmış ve tutuklanmıştı. Biga'ya Ahmet Anzavur'a teslim için götürülürken de vurularak şehit edilmişti Bkz. Uluğ İğdemir, Biga Ayaklanması ve Anzavur Olaylanı(Günlük Anılar), Türk Tarih Kurumu Basımevi, Ankara 1989, s.12-13.

${ }^{42}$ Akbaş silah ce cephane deposundan kaçırılan silahlar Yenice köyünde depolanmıştı ve bu silahları Dramalı Rıza ve adamlan koruyordu. Yenice'deki bu silah ve cephaneler İkinci
} 
yiğit savaşçılarını kaybetmiş olması ve Kuzeybatı Anadolu'da sürdürülen Millî Mücadele için hayati önemi olan silahların ve cephanelerin kendisi tarafından imha edilmesinin yarattığı üzüntü ve moral çöküntüsü Dramalı Rıza Beyin Balıkesir bölgesinden ayrılarak Bursa'ya gelmesine yol açan önemli nedenlerdi ${ }^{43}$.

Ancak bütün bunların yanında bir de Çerkes Ethem faktörü vardı. Anzavur'un İkinci İsyanı'nı bastırmak amacı ile Salihli cephesi kumandanı Çerkes Ethem de kuvvetleri ile Biga bölgesine gelmişti. Dramalı Rıza Bey, Salihli cephesinde Çerkes Ethem ile birlikte mücadele ediyordu. Nitekim her ikisi de Birinci Anzavur İsyanı sırasında Salihli cephesinden yardıma çağrılmışlardı. Anzavur'un tenkili ve takibi görevlerini üstlenmişler ve netice olarak isyan bastırılmış, Anzavur kuvvetleri etkisiz hale getirilmişti. Ancak Çerkes Ethem ile bir türlü geçinemeyen Dramalı Rıza Bey, isyanın bastırılmasından sonra tekrar Salihli cephesine dönmemiş, Balıkesir'de bulunan 61. Fırka Kumandanı Miralay Kazım Bey tarafından, Köprülülü Hamdi Beyin emrine görevlendirilmiş ve Biga'ya gönderilmişti. ${ }^{44}$

İşte Anzavur'un ilk isyanından sonra Salihli cephesine dönmeyen Dramalı Rıza Beyin bu davranışını bir türlü hazmedemeyen Çerkes Ethem, Dramalı Rıza Beyi şiddetle cezalandıracağını, eline geçirdiğinde kendisini asacağını mütemadiyen dile getirmişti. Bu nedenle İkinci Anzavur İsyanını bastırmak için geldiği Balıkesir bölgesinde Dramalı Rıza Beyi aratmaya başlamıștı. Çerkes Ethem'in o günlerdeki gücünü ve acımasızlığını bilen ve kendisini arattığını öğrenen Dramalı Rıza Bey, bir an önce Balıkesir bölgesinden uzaklaşmış ve Bursa'ya gitmişti.

Hacim Muhittin Bey hatıralarında Dramalı Rıza Beyin kendisine başvurmasını şöyle anlatıyor:

"Bu Dramall Rıza hakikaten cesur ve fedakar bir çocuktur. Ben kendisini daha eskiden tantyorum. $O$ zamanlar Çerkes Ethem'in yanında bulunuyordu. Fakat yaradılışı icabı Edhem'in her arzusunu yerine getirmeyecek bir tip olduğu için Edhemle arası açılmış, Edhem de Rızayı

Anzavur İsyanı sırasında asilerin eline geçmemesi için Dramalı Rıza Bey tarafından yakılarak imha edilmişti.

43 "Dramalı Rıza Bey, bu hatasından dolayı karşıma çıkamadı. Pek fedakâr ve hamiyetli bir kimse olan ve büyük hizmetler görmüş bulunan Rıza Bey'in bu gafleti yapmış olması kendisini pek üzüyor ve dövünerek ağlamakta olduğunu işitiyordum. Rıza Bey'in bu taraflarda kalamayarak Bursa'ya gittiğini haber aldım.”Bkz. Özalp, age., C.1, s.99.

${ }^{44}$ Kazım Bey hatıralarında konuyla ilgili olarak şu bilgiyi vermektedir: "Akbaş'daki silah ve cephanenin nakli vazifesini Köprülülü Hamdi Bey üzerine almıştı. Kendisi yanına aldığ 1 10 Kuvayı Milliye askeriyle Balıkesir'den Biga'ya hareket etti. O sırada Gönen havalisinde Anzavur taraftarlarını takip etmekte olan Dramalı Rıza Bey(İstanbul'da idam edilen) Ethem'le arası açıldığından Salihli cephesine dönmemişti. Çok kabiliyetli ve fedakar bir kimse olan Rıza Bey'i 40 asker adamıyla Hamdi Beyin emrine gönderdim” Özalp, age., C.1, s. 90 . 
bertaraf etmeye karar vermiş, fakat bunu anlayan Riza Edhemin yanından kaçıp birkaç arkadaşıyla şurada burada dolaşmaya başlamış ve Edhemin eline düşmemeye çalışmış. O sırada ben de Bursa'da Vali idim, benim Bursa'da olduğumu işiten Rıza kendisini Edhemden kurtarabilecek tek kişi olarak beni gördüğü için bir gün Bursa'ya gelmiş. "45

Dramalı Riza Bey, Bursa'ya gelince, Vali Hacim Muhittin Beye başvurmuş ve ondan kendisini Çerkes Ethem'e karşı korumasını istemişti. Gerçekten de o günlerde Çerkes Ethem'in üzerinde etkili olabilecek kişilerin başında Hacim Muhittin Bey geliyordu. Hacim Muhittin Bey, Dramalı Rıza'ya dostça davranmış ve kendisini iyi bir şekilde karşılamıştı. Ayrıca Dramalı Rıza'ya, Çerkes Ethem ile görüşüp, Çerkes Ethem'in kendisini bertaraf etme kararını değiştirmesini isteyeceğini ve bunda da başarılı olacağını söylemişti. Hacim Beyin bu sözleri Dramalı Rıza Beyi çok rahatlatmı̧ ve memnun etmişti.

Bilahare Hacim Muhittin Bey ve Bursa'da kendisiyle birlikte çalışan Polis Müdürü Nuri ve Jandarma Alay Kumandanı Remzi Beylerle bir istişare yaparak, daha önce İstanbul'daki teşkilât(Karakol) ile kararlaştırılan "Damat Ferit Paşaya suikast teşebbüsü için, Dramalı Rıza Beyden istifade edilmesine karar verirler" . Bu kararın verilmesinde "Dramalı Rıza Beyin, Damat Ferit Paşaya olan tepkisinin de büyük rol oynadığı söylenebilir. Dramalı Rıza Bey bir çok mahfilde "İstanbul'a giderek Damat Ferit Paşayı öldüreceğini" pervasizca dile getirmekteydi ${ }^{47}$.

Hacim Muhittin Bey Damat Ferit Paşayı bertaraf etme işinde Dramalı Rıza Beyi değerlendirme konusundaki kararı aldıktan sonra, kararı Dramalı Rıza Beye açıklamış ve o da bu kararı tereddütsüz ve büyük bir memnuniyetle kabul etmiştir.

Diğer suikastçılardan Bahriye Yüzbaşısı Halil İbrahim Bey, İstinye’de üç Fransız subayını döverek yaralamıştı. Bu nedenle hakkında tutuklama kararı çıkartılmış, o da İstanbul'dan kaçarak Bursa'ya gelmişti. Bursa'daki Kuva-y1 Milliye yöneticileri tarafından inzibat zabitliği görevine getirilmiști. Suikastçılar arasında neden yer aldı ̆̆ı hususunda açık bir bilgi olmamakla birlikte 13 Haziran tarihli Vakit gazetesinde çıkan bir habere göre, Halil İbrahim Bey, bu suikast tertibatına "zaruri nedenlerle" katılmıştı. Suikast

\footnotetext{
${ }^{45}$ Çarıklı, age., s.110.

${ }^{46}$ Age., s.110.

${ }^{47}$ Dramalı Rıza Bey, Akbaş cephaneliğinden kaçırılan silah ve cephanenin Yenice'de kendisi tarafından imha edilmesi hadisesine çok üzülmüştü. Bu olaylara yol açan Anzavur Ahmet İsyanı'nın arkasındaki gücün Damat Ferit Paşa olduğuna inanan Dramalı Rıza Bey, Damat Ferit Paşayı öldürüp bir anlamda intikam almayı düşünmekteydi. Bu konuda bazı eserlerde verilen bilgiler mevcuttur. İngiliz Kemal hatıralarında:"Dramalı Rıza buna sebep olan Ferit Paşa'dan intikamını almak için yemin etmişti, Bu intikamını almak maksadıyla İstanbul'a gitmiş, Ferit Paşa'ya suikast hazırlamıştı" demektedir Bkz. Recai Sanay, Türk Casusu Ingiliz. Kemal İstiklâl Harbinde, Nebioğlu Yay. İstanbul 1958,
} 
öncesi verilen ve sonrası için de mükafat olarak verileceği vaat edilen paraya son derece ihtiyacı olduğunu, alacağı bu parayla geçimini temin edeceğini ve istikbalini garantileyeceğini sorgusunda söylemiști Bu nedenle kendisinin mazur görülmesini istemişti. ${ }^{48}$

Suikastçılardan Bursa Yenişehirli Hasan ve Bursalı çoban İsmail'in suikastçılar arasına hangi nedenle katıldıkları konusunda bir bilgi yoktur. Büyük bir ihtimalle gözüpek ve bu suikastı gerçekleştirebilecek ehliyette olmaları nedeniyle suikastçıların arasına alındığını düşünmekteyiz. Ayrıca suikast öncesi verilen avans mahiyetindeki para ile sonrası mükafat olarak verilecek külliyetli miktardaki paranın da bu kişilerin suikast girişimine dahil olmalarındaki rolü büyüktü.

\section{SUIKASTCILARIN ISTANBUL'A GÖNDERILMESI VE BURADAKI FAALIYETLERI}

Dramalı Rıza Bey, suikastı birlikte gerçekleştireceği Bahriye Yüzbaşısı Halil İbrahim Bey ve beraberlerinde kimlikleri konusunda açık bilgi bulunmayan ve sadece Bursa Yenişehirli Hasan ile Bursalı Çoban İsmail olarak mahkeme kayıtlarında yer alan şahıslarla birlikte Bursa'dan hareket etmişlerdir $^{49}$. Bursa'dan hareketlerinde Bursa Jandarma Alay Kumandanı Remzi Bey tarafından İstanbul'daki bazı teşkilât mensubu zevata verilmek üzere yazılan ve suikast için gerekli talimatların yer aldığı sekiz adet mektup, ayrıca İstanbul'daki harcamaları için de bir miktar para avans olarak kendilerine verilmişti ${ }^{50}$.

Dramalı Rıza Bey ve arkadaşları, 18 Mayısta akşam saatlerinde Armutlu'lu Mehmed Kaptan'ın kayığıyla Haydarpaşa-Kadıköy arasındaki sahilin tenha bir yerinde karaya çıkmışlardı. O gece Haydarpaşa'da bir otelde kalan suikast ekibi, sabahleyin Bahriye Yüzbaşısı Halil İbrahim'in gayet iyi tanıdığı ve dostu olan Mehmet Ali Beyin evine gitmiş ve suikast meselesini ona açmış ve onun da muvafakatini aldıktan sonra üzerlerinde bulunan silah ve mektupları Mehmet Ali Beyin evine bırakmışlardı ${ }^{51}$.

\footnotetext{
${ }^{48}$ Vakit, 13 Haziran 1336(1920), Nr.917.

${ }^{49}$ Çarıklı bu konuda "Günün birinde üç kişi olarak Dramalı Rıza'yı İstanbul'a gönderdik" demekte şahısların ismini ve hareket tarihlerini belirtmemektedir. Bkz. Çarıklı, age., s.110.

${ }^{50}$ Dramalı Rıza Bey ve arkadaşlarına Bursa'dan hareketlerinde avans mahiyetinde verilen paranın miktarı konusunda da farklı rakamlar söylenmektedir. Çarıklı,"ben diğerleriyle ayrıca yaptığım gibi Rıza'ya da üç yüz lira para vermiştim ki( o zaman için mühim bir meblağ idi)" demektedir. Çarıklı, age., s.110. Diğer taraftan Alemdar gazetesinde İstanbul Polis Müdürü olan Tahsin Bey, olay ile ilgili olarak gazetecilere bilgi verirken "Bursa'dan hin-i hareketlerinde kendilerine bilahare ikişer bin lira mükafat verilmek üzere, peşinen beşer yüz lira verilen Halil İbrahim ve Rıza..." suikastı yapacak olanlara beşer yüz lira avans mahiyetinde ödendiğini belirtmektedir. Alemdar, 2 Haziran 1336(1920), Nr.529/2829.

${ }^{51}$ BOA, DUIT, Nr.79/5-117.
} 
Daha sonra Dramalı Rıza, Halil İbrahim ve Mehmet Ali Bey ile birlikte İstanbul'a inmişler ve Dramalı Rıza ile Halil İbrahim Bey kıyafetlerine çeki düzen vermek amacıyla elbise, ayakkabı, gözlük ve gümüş baston satın almışlardı $^{52}$. Sonra da Halil İbrahim Bey kendi evine gitmek için diğer arkadaşlarından ayrılmış, Dramalı Rıza ile Mehmet Ali Bey Mühürdarı da bulunan umumhaneye gitmişler ve iki gün süreyle burada kalıp, eğlenmişlerdi.

Daha sonra Üsküdar'a dönen Dramalı Rıza Bey ile Mehmet Ali Bey, burada bulunan mektupları alarak, Jandarma Alay Kumandanı Binbaşı Remzi Beyin evine gitmişler ve orada Remzi Beyin hanımına hitaben yazdığı mektubu vermişler ve onun vasıtasıyla Binbaşı İhsan Bey ile evinde görüşmüşlerdi. Bu arada kendilerine vaktiyle İttihat ve Terakki Cemiyeti'nin Üsküdar Kulübü Başkanlığını yapmış Tevfik (Sükûti) Bey katılmıştı.

Dramalı Rıza Beyin de içinde bulunduğu bu grup hep birlikte Binbaşı İhsan Beyin evine gitmişler ve burada Tevfik Bey ile İhsan Bey adına Remzi Beyin gönderdiği mektupları sahiplerine vermişlerdir. İhsan Beyin evinde suikastın nasıl yapılacağı üzerine ön görüşme yapılmış ve daha sonra da Tevfik Bey, Dramalı Rıza Beyi kendi evine davet etmiş ve Dramalı Rıza Bey geceyi burada geçirmiştir. Ertesi gün Dramalı Rıza Bey, Tevfik Beyin evine gelen Binbaşı Adil Bey ile tanışmış, burada suikast meselesi tekrar ele alınarak tartışılmıştı. Bu görüşmeden sonra bu kez de Adil Beyin biraderi Ahmet Halim ve onun ticari ortağı olan Tolcalı Süleyman Beyin yazıhanesine gidilmiştir. Bu görüşmede Bursa Jandarma Alay Kumandanı Binbaşı Remzi Beyin Tolcalı Süleyman Beye hitaben yazdığı mektup, kendisine verilmişti.

Aynı günün akşamı suikasttan haberdar olan ve bu teşebbüsün İstanbul ayağını oluşturan ekip ve Dramalı Rıza ile birlikte Tolcalı Süleyman Beyin evinde bir araya gelmişler ve suikastın nasıl yapılacağı konusunu tekrar görüşmüşlerdi. Bu görüşsmeye ismi mahkeme kayıtlarında belirtilmeyen bir Erkân-1 Harb Miralayı da katılmıș ve suikastın yapılması ile ilgili, onun tarafından yapılan keşifler değerlendirilmişti. Erkân-1 Harb Miralayı'nın suikastın Damat Ferit Paşanın sarayı önünde yapılmasının güç olacağı, en uygun yerin Harbiye Nezâreti'nin bahçesi olduğu şeklindeki görüşü benimsenmişti. Suikastın Perșembe günü Damat Ferit Paşanın Harbiye Nezâreti'ne geldiği sırada, nezâretin bahçesinde otomobilinden inerken yapılmasına karar verilmişti ${ }^{53}$.

Bu görüşme esnasında Dramalı Rıza Bey ile arkadaşlarının kendilerine Bursa'da iken vaat edilen paranın temin edilmesi hususundaki talepleri, teşkilâtın(Karakol) kasasında bu paranın olmadığı, parayı Bursa'dan istemek durumunda olacakları görüşülmüş ve Bursa'ya bu para meselesi ve suikast

${ }^{52}$ BOA, DUIT, Nr.79/5-117.

${ }^{53}$ BOA, DUIT, Nr.79/5-117. 
ile ilgili bütün hazırlıkların tamamlandığına ilişkin bir kart yazılıp, gönderilmesine karar verilmişti ${ }^{54}$.

Suikastı icra edecek olan Dramalı Rıza Bey ve arkadaşlarına, suikast için gerekli silah ve bombaların bir kısmı verilmiş, suikastın başarıyla gerçekleştirilmesi için gereken "dört adet polis revıveri ve altı İngiliz bombasının da" en kısa zamanda tamamlanacağı Tolçalı Süleyman Bey tarafından ifade edilmişti. Ayrıca Tolçalı Süleyman Bey, Dramalı Rıza Beye hitaben, şayet bu suikastı başarıyla gerçekleştirirlerse, kendilerine beşer bin lira mükafat verileceğini ve tarihe isimlerinin altın kalem ve yazı ile yazılacaklarını söylemişti. Bu toplantının yapıldığı gece Dramalı Rıza Bey Tolçalı Süleyman Beyin evinde kalmıştı. Ertesi sabah Tolçalı Süleyman tarafından, iki gün sonra tekrar görüşülmesi ve bu görüşme esnasında da silah ve bombaları kendilerine teslim edeceği hatta belki de vaat edilen paranın da verileceği söylenmiş ve taraflar ayrılmışt1 ${ }^{55}$.

Divân-1 Harb-i Örfi'ce verilen hüküm gerekçesinde yukarıdaki anlattıklarımız belirtildikten sonra "Nihayet Riza Bey tarafindan Polis Müdüriyet-i Umûmiyesine vaki olan ihbarat üzerine içlerinden mevkuf bulunanların derdest edildikleri ${ }^{\prime 56}$ belirtilmek suretiyle suikast teşebbüsünü Dramalı Rıza Beyin İstanbul Polis Müdüriyetine ihbar ettiği açıklanmaktadır.

\section{SUIKAST GİRIŞIMINIIN AÇIĞA ÇIKMASI}

Damat Ferit Paşaya düzenlenecek suikast ile ilgili "suikastın yapılacağı gün ve yer de dahil olmak üzere" tüm hazırlıkların yapıldığı bir sırada, yapılan bir ihbar üzerine başta Dramalı Rıza Bey olmak üzere bir çok şahıs tutuklanmıştır. İstanbul Polis Müdüriyetine bu ihbarın Dramalı Rıza Bey tarafından yapıldığı, Divan-1 Harbin verdiği gerekçeli kararda da belirtilmiştir. Ancak bu ihbarın kimin tarafından yapıldığı, hatta böyle bir ihbar olmayıp, İstanbul Polis Müdüriyetinin, bu suikastın yapılacağını baştan beri bildiği konusunda bazı kaynaklarda değişik bilgiler verilmiştir. Şimdi bu hususta konunun aydınlatılmasında oldukça önemli gördüğümüz bilgileri vermeye çalışacağız.

Hacim Muhittin Bey hatıralarında Dramalı Rıza Beyin doğrudan bir ihbarda bulunmadığını ancak alkollü olduğu bir sırada boşboğazlığı yüzünden kendisini ve suikast teşebbüsünü ağzından kaçırdığını belirtmektedir. Hacim Muhittin Beyin bu konuda anlattıkları şöyledir:

"Tertip yolunda ve yapacak arkadaşlar da hakikaten ehil idiler. Fakat Rıza Istanbul'a gidince Ferid Paşa işini halletmezden evvel şöyle, felekten bir kâm almak hevesine düşmüş olacak ki Kadıköy'ündeki randevu

\footnotetext{
${ }^{54}$ BOA, DUIT, Nr.79/5-117.

${ }^{55}$ BOA, DUIT, Nr.79/5-117.

${ }^{56}$ BOA, DUIT, Nr.79/5-117.
} 
evlerine devama başlamış. Eğlence esnasında ve alkolün tesiri ile övünmek için, yapacă̆ı işi ve bizim tarafımızdan gönderildiğini ă̆zından kaçırmış ve hükûmete ihbar edilince yakalanmışlar, bu defa tazyîke mukavemet edemeyerek her şeyi itiraf etmis, nihayet idama mahkum olarak idam edilmiştir." 57

Zühtü Güven, Dramalı Rıza Beyin suikast teşebbüsü için İstanbul'da bulunduğu günlerde, Yenice nahiyesi muhtarı olan ve bir iş için İstanbul'da bulunan Ali Bey tarafından görüldüğg̈ ve tanındığını söylemekte ve devamla Ali Beyin hemen Anzavur'un has adamı olan Şah İsmail ve arkadaşlarına haber verdiğini, onların da Dramalı Rıza Beyi yakalattırdıklarını belirtmektedir ${ }^{58}$.

Suikast teşebbüsünün ortaya çıkmasında ve İstanbul'daki Karakol teşkilâtının if̧̧a edilip, bir çok üyesinin tutuklanmasında ihbarcı olarak Dramalı Rıza Beyi suçlayanlardan birisi de Hüsamettin Ertürk'tür. Ertürk, Dramalı Rıza'nın İstanbul'a gelince Tolcalı Süleyman'dan önce İstanbul Polis Müdürü olan Kalkandelenli Hasan Tahsin'le ilişki kurduğu ve suikast ile ilgili bilgileri ona anlattığı ve kendisiyle de irtibata geçerek, bu teşebbüsün içine kendisini de çekmek istediğini söylemektedir. ${ }^{59}$

Başka bir anlatımda da, suikastla ilgili bütün hazırlıkların bitirilip, suikastın yapılmasına geçileceği bir sırada, Dramalı Rıza Bey ile arkadaşları arasında, para meselesinden çıkan bir anlaşmazlık dolayısıyla, Dramalı Rıza Beyin İstanbul Polis Müdürlüğüne giderek, tertibattan Polis Müdürlüğünü haberdar ettiği ve bunun karşılığında da hayatının bağışlanacağı ve affedileceği vaadinin kendisine resmen verildiği rivayet olarak anlatılıyordu denilmektedir ${ }^{60}$.

Çerkes Ethem ise, Dramalı Rıza Beyin, ele geçmesi ve kısa bir muhakemeden sonra yargılanarak idam edilmesinde, Millî Mücadele'nin o buhranlı günlerinde çok sık rastlanılan "kancıklık ve alçaklığın" rol oynadığını belirtmekte ve devamla Dramalı Rıza Beyin ihbar edildiğini, kendisinin de yakalandıktan sonra asla inkâr etmediğini ve akıbetine gözünü kapamadan gittiğini belirtmektedir ${ }^{61}$.

Damat Ferit'e yapılan suikastın ele alındığ Harbin Mazbata-i Hükmiyesi'ne" atıf yapılarak suikastı Dramalı Rıza Beyin

\footnotetext{
${ }^{57}$ Çarıklı, age., s.110-111.

${ }^{58}$ Güven, age., s.75.

${ }^{59}$ Ertürk, Hüsamettin Ertürk, Millî Mücadele Senelerinde Teşkilât-l Mahsusa, Daktilo Metin (Yay. Haz. Tevfik Apay Genelkurmay ATASE Kütüphanesi, Ankara 1985, s.282-284.

${ }^{60}$ Tarık Mümtaz Göztepe, "Nemrut Mustafa'nın Astığı Kuvayı Milliyeciler”, Dün ve Bugün, Y1l:1, C.1, S.12,(20 Ocak 1956), s. 6.

${ }^{61}$ Kutay, age., s. 20-21.
} 
ihbar ettiği ve bu ihbar hadisesinde de kendisine vaat edilen parayı alamamış olmasının temel neden olduğu belirtilmektedir ${ }^{62}$.

Görüleceği gibi suikastın ihbarı konusunda farklı anlatımlara yer verilmektedir. Biz de bu anlatımlara bir yenisi ekleyeceğiz. Bütün bu söylenenlerin tam aksine suikastın Dramalı Rıza Bey tarafından ihbar edilmediği, aksine İstanbul Polis Müdüriyeti'nin suikast teşebbüsünden çok önceden haberdar olduğu, suikastın kimler tarafından kimlere yapılacağı, suikastı yapacak kişilerin ismen ve hatta şeklen bilindiği, bunun dışında suikast teşebbüsünün İstanbul ayağının deşifre edildiğini belirtmeye çalışacağız. Bu konudaki bilgilerin dayanak noktası ise İstanbul Polis Müdüriyet-i Umumisi görevini yürütmekte olan Hasan Tahsin Beyin, basına suikast ile ilgili verdiği bilgiler ve yaptığı açıklamalar olacaktır.

2 Haziran 1920 tarihli Alemdar gazetesinde "Suikast Meselesi Tafsilât ve Teferruatı" başlığıyla verilen bir haberde, suikast meselesi hakkında geniş açıklamalarda bulunulmuştur. Haberin içeriğinde "suikasttan nasıl haberdar olunduğuna" ilişkin bir alt başlık bulunmaktadır. Burada anlatılanlara göre İstanbul Polis Müdüriyeti'nin suikasttan haberdar olması şöyle gelişmiştir ${ }^{63}$ :

Trakya'da Millî Mücadele lehine teşkilât kurmakla ve burada mücadeleyi başlatmakla görevli bir teşkilât mensubu, Karakol Cemiyeti'nin İstanbul'daki Heyet-i Merkeziye Reisi olan ve ticaretle uğraşan Tolçalı Süleyman Beye bir mektup yazmıştır. İlgili şahıs bu mektubunda Edirne'de kurmaya çalıştı̆̆ı teşkilâtta başarılı çalışmalar yapabilmesi için teşkilâtına mali yardım yapılması gerektiğinin Ankara'ya bildirilmesini Tolcalı Süleyman Beyden istemiştir. Ayrıca mektubunda İstanbul'da icrasına karar verilen suikast neticesinin kendisine bildirilmesini de istemiştir. İşte Edirne'den yazılan bu mektup, İstanbul Polis Müdürü Umumisi olan Hasan Tahsin Beyin eline geçmiştir. İstanbul Polis Müdürü, mektubun içeriğinden Sadrazam Damat Ferit Paşaya karşı bir suikast tertip edilmek üzere bulunulduğunu anlamıştı. Mektuptaki bilgilerden suikast tertibinin içinde yer alan bazı kişiler ismen öğrenilmişti. Ancak Polis Müdürü Hasan Tahsin Bey, gerek bu kişilerin ve gerekse bunlara yardım ve yataklık etmekte olan diğer arkadaşlarının daha kesin deliller ile yakalanması için, bu meseleyi takip etmek üzere Üsküdar bölgesi Polis Müfettişi Kemal Beyi görevlendirmişti.

Harekete geçen Üsküdar bölgesi Polis Müfettişi Kemal Bey, mektupta yer alan isimlerden birisi olan Bağlarbaşı'nda Birinci Muhafız Tabur Kumandanı Binbaşı Osman Bey ${ }^{64}$ ile bağlantı kurmaya çalışır. Kendini öğretmen olarak tanıtan Kemal Bey, çocuklarına ders vermek konusunda

${ }^{62}$ M. Yavuz Erler,"Damat Ferit'e Suikast" Atatürk Üniversitesi, Atatürk İlkeleri ve İnkılâp Tarihi Enstitüsü Atatürk Dergisi "Doç. Dr. Günay Çağlar Özel Sayısı", Cilt III, Sayı:2, (Temmuz 2002), s.114-115.

${ }^{63}$ Alemdar, 2 Haziran 1336(1920), Nr.529/2829.

${ }^{64}$ BOA, DUIT, Nr.79/5-117. 
Binbaşı Osman Bey ile bağlantı kurar. Binbaşı Osman Bey ile de samimiyetini artıran Kemal Bey, zaman zaman binbaşı ile siyasî konularda sohbet etmeye başlar. Bu sohbetler esnasında kendisinin de "mevcut hükûmetin hasm-1 canı olduğunu" söyleyerek Binbaşı Osman Beyin kendisine güven duymasını sağlar.

Öğretmen olarak bildiği Kemal Beyin, siyasî olarak kendisi ile aynı fikir ve amaçlar taşıdığına inanan Binbaşı Osman Bey, Kemal Beyden istifade etmeyi düşünerek, ona, İstanbul'daki teşkilâtları hakkında geniş açıklamalarda bulunduğu gibi Damat Ferit Paşaya düzenlenecek suikast ile ilgili planları da açıklar. Hatta Kemal Beyden, kendi teşkilâtlarına katılmasını istemiş, Kemal Bey de büyük bir memnuniyet ile bunu kabul etmiştir.

Artık İstanbul Polis Müdürü Hasan Tahsin Bey, Kemal Bey vasıtası ile İstanbul'daki teşkilâtın (Karakol) her toplantısından ve faaliyetlerinden haberdar olmaya başlamıştır. Teşkilâtın suikast tertibi ile ilgili bütün planları da öğrenilmiștir. Hatta suikastı gerçekleștirecek olan Dramalı Rıza ile Bahriye Yüzbaşısı Halil İbrahim Bey ve arkadaşlarının İstanbul'a geldikleri ve faaliyetleri de öğrenilmiştir. Suikastın kimlere karşı düzenleneceği, tetikçilerin kim olduğu, İstanbul'daki teşkilâtın bu suikast ile olan bağlantısı, yapılan toplantılar ve bu toplantılara kimlerin katıldığı, Bursa ile olan yazışmalar İstanbul Polisi için artık sır olmaktan çıkmıştır. Suikast tarihi ve yerinin yapıldığı son toplantıda görüşülenlerden de haberdar olan İstanbul Polis Müdürü Hasan Tahsin Bey artık harekete geçilmesine karar vermiş ve Üsküdar Polis Müfettişi olan Kemal Beye, Dramalı Rıza ile Bahriye Yüzbaşısı Halil İbrahim Beyi yakalamak emrini vermiştir.

Dramalı Rıza ile Bahriye Yüzbaşısı Halil İbrahim'in aranması işi Beyazıt Polis Şubesi'ne verilmiştir. Artık her yerde suikastın tetikçileri aranmaya başlanmıştır. Üsküdar polis Müfettişi Kemal Bey, Beyazıt Polis şubesine gittiği bir anda Yüzbaşı Halil İbrahim Bey ile tesadüfi bir şekilde yolda karşı karşıya gelir. Kemal Bey, artık tamamen ortaya çıkmış olan suikast meselesi konusunda daha fazla beklemenin gereği olmayacağını düşünerek hemen o anda Bahriye Yüzbaşısı Halil İbrahim Beyi tutuklamak amacıyla silahını çeker, Halil İbrahim Bey ise ani bir hareketle elinde taşıdı ̆̆ çantanın içinden küçük bir parebellum silah çıkartmışsa da, Kemal Bey tarafından etkisiz hale getirilmiş ve yakalanarak İstanbul Polis Müdüriyetine götürülmüştür.

İstanbul Polis Müdürlüğüne götürülen Bahriye Yüzbaşısı Halil İbrahim Bey, daha ilk tahkikât esnasında, suikast teşebbüsü hakkında gereken bütün bilgiyi anlatmıştır. Böylece suikast ile irtibatlı olan ismi bilinenlerin dışında bilinmeyen kişiler de öğrenilmiş ve seri bir şekilde bunlar Polis tarafından yakalanarak, tutuklanmışlardır. Tutuklanan bu kişiler arasında Dramalı Rıza Bey de vardır. 
Görüleceği gibi suikastın ihbarı meselesinde Dramalı Rıza Beyin hiçbir rolü bulunmamaktadır. Aslında ortada bir ihbar da yoktur. Olay baştan beri İstanbul polisince öğrenilmiş ve takibe alınmıştır ${ }^{65}$. Yukarıdaki anlatımlar doğrudan bu işle ilgili tahkikâtı yürütmüş olan İstanbul Polis Müdürü Hasan Tahsin Beyin anlatımlarıdır. Üstelik bu anlatımlar suikastçıların yakalandıkları ilk günlerde (2 Haziran 1920) basına yapılmıştır. Oysa Dramalı Rıza Beyin ihbarcı olarak ifade edildiği gerekçeli karar, bu açıklamalardan bir hafta sonra Divan-1 Harb-i Örfi tarafından yazılmış ve 13 Haziran tarihli gazetelerde yayınlanmıștır ${ }^{66}$. Gerekçeli kararda Dramalı Rıza Beyin ihbarcı olarak belirtilmesi, kanaatimizce, Millî Mücadelemizin bu gözüpek, yiğit ve hatta kahraman olarak nitelendirilen değerli bir mensubunun şahsında bütün bir Millî Mücadele hareketini "küçük düşürme" amacından kaynaklanmıştır.

Burada şunu da hemen belirtmemiz gerekir ki, Dramalı Rıza Bey, soruşturma esnasında, ama yapılan tazyik ve işkenceden, ama kendisinin affedileceği ve serbest bırakılacağ 1 vaadinden olsa gerek, bazı ifşaatlarda bulunmuş ve bilhassa İstanbul'da tanıdığı teşkilât(Karakol) mensuplarının isimlerini bir liste olarak vermiştir ${ }^{67}$. Bu yaptığı elbette doğru değildi. Ancak henüz daha 30 yaşında olan bir insanın idamdan kurtulmak için bu ifşaatı bir çıkış yolu olarak da görmüş olduğunu düşünmekteyiz.

\section{SUIKAST ILE ILGILI GÖRÜLENLERIN TUTUKLANMASI}

Suikast girişimi açığa çıktıktan sonra, İstanbul Polis Müdüriyeti hızla, bu tertip içinde yer alan şahısları tutuklamaya başlamışıtı. Nitekim, Bahriye Yüzbaşısı Halil İbrahim Bey ve Dramalı Rıza Bey ilk tutuklanan kişiler arasındaydı. Gerek daha önce isimleri bilinen ve suikastın İstanbul ayağını oluşturan Karakol Cemiyeti'ne mensup kişiler ve gerekse Halil İbrahim ile Dramalı Rıza Beyin tazyik ve işkence altında verdikleri isimler birer birer tutuklanmaya başlanmıştı. Gazetelerde de hem suikast ile ilgili hem de tutuklananların isimleri ile ilgili haberler çıkmaya başlamıştı.

Suikast ile ilgili ilk haberler 1 Haziran tarihli İstanbul gazetelerinde yer almaya başlamıştı. Alemdar gazetesi "Suikast Mürettiplerinin Tevkifi" başlıklı yazısında öncelikle Dramalı Rıza Bey ile Bahriye Yüzbaşısı Halil İbrahim'in isimlerini vererek bunlar hakkında "Salihli Kuva-yı Milliye Reisi olub Akbaș camiini içerisindeki yüzlerce çoluk ve çocukla yakan eşirradan

${ }^{65}$ Ankara üniversitesi Türk İnkılâp Tarihi Enstitüsü Arşivi(TITE)'nde rastladığımız bir belgede İngiliz ajanı ve misyoneri Papaz Frew'in İzmir civarından gönderdiği bir telsiz telgraf ile Dramalı Rıza Beyin suikast teşebbüsü için İstanbul'a gideceğini Sait Molla'ya bildirmiştir. Üstelik bu telgrafı Dramalı Rıza Beyin İstanbul'a gitmesinden 1,5 ay önce göndermiştir. Bu bilgi için bkz. TITE Arşivi, Dosya No: 63, Gömlek No: 26, Belge No: 26

${ }^{66}$ Vakit, 13 Haziran 1336(1920), Nr.918; Alemdar, 13 Haziran 1336(1920), Nr.540/2840; Peyam-l sabah, 13 Haziran 1336(1920), Nr.556/10986.

${ }^{67}$ BOA, DUIT, Nr.79/5-117.; Vakit, 13 Haziran 1336/1920), Nr.918; Alemdar, 13 Haziran 1336(1920), Nr.540/2840; Peyam-l sabah, 13 Haziran 1336(1920), Nr.556/10986. 
Dramalt Rıza ile mütarekeden sonra İstinye'de iki şahsı cerh eylemesinden dolayı hal-i firârda bulunan Bahriye yüzbaşılarından Halil İbrahim Efendi" diyerek suikastın bizzat bunlar tarafından yapılacağını yazıyordu ${ }^{68}$. Gazetede daha sonra diğer tutuklananların ismi verilmişti. ${ }^{69} 2$ Haziran tarihli bir çok İstanbul gazetesi, suikast teşebbüsüne geniş yer ayırmış ve suikastçıların tutuklandığını yazmıştı ${ }^{70}$. Sonraki günlerde basının suikast davasına olan ilgisi devam etmiş, mütemadiyen her gün suikast davası ile ilgili haberler yayınlanmıştır. Ayrıca Alemdar'da Refi Cevad, Peyam-l Sabah'da Ali Kemal de yazdıkları yazılarla, suikastçıların şiddetle cezalandırılmasını istiyorlardı. Nitekim Refi Cevad, "Memleketin bu dahili düşmanlara karşı bu lakaydi devam etdikçe, suikastların, cinâyatların hiçbir zaman arkası alınmayacakdır. Hükûmet bu mes'eleyi lâzım gelen şiddet ve ehemmiyetle takîb eylemelidir, Memleketin huzûru namına buna muhtacız" "71" demekte, Ali Kemal ise "Bu Canavarlar Böyle Bırakılmaz" suikasttan yargılananların kısa zamanda hak ettikleri cezayı bulmalarını istemiştir.

Gazetelerde çıkan haberlerde, Kuva-yı Milliye'nin İstanbul da oluşturduğu teşkilâtının da mahiyetinin anlaşıldığı yazılmıştı. Bu haberlere göre İstanbul'da bu gizli teşkilât on şubeye sahipti. Yürütülen araştırma ve takip sonucu teşkilâtın değişik şubelerine mensup, çok sayıda kişi tutuklanmıştı. Bunlar arasında Erkân-1 Harbiye Miralaylarından Aziz Samih,

${ }^{68}$ Alemdar, 1 Haziran 1336(1920), Nr.528/2828.

${ }^{\oplus}$ Bunların isimleri de şöyleydi:

"Bu hareketin muîn ve müşevviki oldukları anlaşılan tüccardan Tolcalı Süleyman ve şerîki Ahmet Halim Beyler ile Ahmed Halim Beyin biraderi Süvari Binbaşılarından Adil Bey ve bunlara yataklık eden Üsküdar Daire-i Belediyesi me'murlarından Mehmet Ali ve Muhassasat-1 Umumiye halifesinden Tevfik Beyler de tevkîf edilmişlerdir.

Bundan maada suikast failleri gerek harekât-1 cinâyetkerânelerine mübâşeretden evvel ve gerek fi'l-i ba'de-l icrâ saklamak teşebbüsât ve istihzarâtında bulunan Bağlarbaşı'ndaki Birinci Muhafız Taburu Kumandanı Osman ve yüzbaşılardan Bican Efendilerile Enver'in sabık yaverlerinden Yüzbaşı Hasan Tahsin ve Mülâzım Rüşdi Efendiler de taht-1 tevkîfe alınmışlardır.

İcrâ edilen tahkikât ve takibât neticesinde kuva-yı gayr-i milliyecilerin İstanbul'da vücûda getirdikleri teşkilâtın da mahiyeti anlaşılmış ve mezkûr teşkilâtın şehrimizde on şubeye malîk olduğu tahakkuk etmiştir. Mezkûr şuabata mensûb eşhasdan bir çoğu taht-1 tevkîfe alınmışlardır. Bunların meyânında Erkân-1 Harbiye Miralaylarından Aziz Sami, Yüzbaşı Hasan ve Fethi, Ahz-1 Asker Şubesinden Kemal ve Maslub Kemal'in cenazesi ihtifâlini tertîb idenlerden ve Sıhhıye Yüzbaşılarından Ali Rıza Efendi ve Üsküdar İmamı Hafız Nuri Efendiler vardır" Alemdar, 1 Haziran 1336(1920), Nr: 528/2828 Aynı mahiyetteki haberler için bkz. Vakit, 1 Haziran 1336(1920), Nr. 905.; Peyam-ı sabah, 1 Haziran 1336(1920), Nr. 544/10974;

${ }^{70}$ Alemdar, 2 Haziran 1336(1920), Nr: 529/2829 ;Vakit, 1 Haziran 1336(1920), Nr. 906; Peyam-l sabah, 1 Haziran 1336(1920), Nr. 545/10975.

${ }^{71}$ Alemdar, 3 Haziran 1336/1920).Nr. 530/2830.

${ }^{72}$ Peyam-l Sabah, 10 Haziran 1336(1920), Nr. 553/10983 
Yüzbaşı Hasan ve Yüzbaşı Fethi, Ahz-1 Asker Şubesi'nden Kemal Bey, Yüzbaşı Ali Rıza ve Üsküdar İmamı Hafız Nuri gibi kişiler bulunmaktaydı ${ }^{73}$.

İstanbul Polis Müdürlüğü'nce suikast davasıyla ilgili görülerek tutuklanan şahıslar şunlardı:

"Dramalı Rıza Bey

Bahriye Yüzbaşısı Halil İbrahim Bey

Maliye Nezâreti Muhassasat-1 Zâtiye ve Mâ'zulin Şubesi mümeyyiz-i evveli Tevfik Bey

Üsküdar Belediyesinin Doğancılar mevkii memuru Mehmet Ali Bey

Komisyonculukla müştagil Adil Bey

Dersaadet Jandarma Taburu Kumandanı Rizeli Binbaşı Raşid Bey

Harbiye Nezaretine merbût Esliha ve Mühimmat Muayene-Tecrübe Hey'eti Esliha-i Hafife Şubesi ve Piyade Talim ve Terbiye Encümeni Azası Piyade Binbaşı Cemal Bey

Yüzbaşı Bican Efendi

Üsküdar'da Mihrimah Sultan camii şerifinin hatibi Üsküdarlı Hafiz Nuri Efendi

Kuşcubaşızade meşhur çeteci Çerkes Eşref'in küçük biraderi Ahmet Efendi

Yüzbaşılıktan müsta'fi ve ziraatla meşgul Köprülülü Hasan Adlî Bey

Süvari Küçük zabit mektebi Birinci Bölük Kumandanı Yüzbaşı Hasan Tahsin

Gülhane cephane anbarları me'muru Yüzbaşı Ahmet Kemal

Süvari Binicilik Mektebi bölük zabiti Mülazım-1 evvel Rüşdü Efendi

Açıkta Yüzbaşı İhsan Efendi

Mütekaid Erkân-1 Harbiye Miralayı Aziz Samih"74

Yine suikast davası ile ilgili görülüp, İstanbul Polis Müdüriyeti'nce haklarında tutuklama kararı çıkarılan, ancak yakalanamayan ve aranmakta olan şahıslarda şunlardı:

“Bursa'da 56. Firka Kumandanı Miralay Bekir Sami

\footnotetext{
${ }^{73}$ Alemdar, 1 Haziran 1336(1920), Nr: 528/2828

${ }^{74}$ BOA, DUIT, Nr.79/5-117.;
} 
Karesi mutasarrıf-1 sabıkı olub Kuva-yı Milliye nâmı altında müteşekkil fitne-i bagiye tarafından Bursa Vilayeti valiliğine tayin edilmiş olan Hacim Bey

Üsküdar Jandarma Taburu Kumandanı olub ahiren firar ile Bursa'ya giderek usât-ı merkûmeye iltihak ve Bursa Jandarma Kumandanlığını deruhte etmiş olan Binbaşı Remzi Bey

Bursa Polis Müdüriyetini ifa etmekte olan Nuri Efendi

İstanbul Jandarma Taburu Kumandanlığından mütekaid Tolcalı Süleyman Bey

Sahra Topçu Binbaşılı̆̆ından mütekaid Üsküdarlı İhsan Bey

Muamelât-1 zatiye kıdemli Yüzbaşısı Ali Rıza Bey

Muhafız Alayının Birinci Tabur Kumandanı Binbaşı Rizeli Osman Bey

Daire-i Harbiye Binbaşııı İsmail Hakkı Bey

Ticaretle Meşgul Resneli Osman Fahri Bey,

Süvari Yüzbaşılığından mütekaid İzzet Canbolat Bey

Ziraat Bankası Memurin Kalemi ketebesinden Ahmet Halim Bey

Şehremaneti memurin-i sabıkasından İbrahim Ago

Dava Vekili Baha Bey

Kayıçıı Armutlulu Mehmet Kapdan"75

Yukarıda isimlerini verdiğimiz bu kişilerin dışında suikast tertibinin ortaya çıktığı ilk günlerde İstanbul Polis Müdüriyetince tutuklanan ve aranan daha bir çok şahıs olmuştu. Bazıları da tutuklanmakla birlikte soruşturmayı yürüten Polis Müdürlüğü'ndeki ve Divan-1 Harb-i Örfisi'ndeki yetkili kişiler tarafından serbest bırakılmış, hatta İstanbul'u terk etmeleri tavsiye edilerek, kaçmalarına göz yumulmuştu. Bunlardan birisi de Hüsamettin Ertürk'dü. Bilindiği gibi Ertürk, Teşkilât-1 Mahsusa'nın son başkanlığını yapmıştı. İstanbul'da kurulan Karakol Cemiyeti'nin Topkapı şubesinin başkanlığını yapmaktaydı. Hüsamettin Ertürk, "Padişah'a ve Sadrazam Damat Ferit Paşaya suikast tertip etmekle ve hükûmeti devirmeğe teşebbüs ile, İstanbul'da miktarı 50 bini bulan gizli müsellah kuvvetleri teşkilâtlandırmakla itham edildiğinden" İstanbul Polis Müdüriyeti'nce yakalanmıştı. Bilahare Divan-1 Harb-i Örfisi'nde yargılamalar başladığında,

\footnotetext{
${ }^{75}$ BOA, DUIT, Nr.79/5-117;
} 
bu mahkemenin başkanlığını yapan (Nemrut) Mustafa Paşa ile yaptığı görüşme sonucu mahkemenin kararı ile tahliye edilmişti ${ }^{76}$.

Yine tutuklandıktan sonra Polis Müdürlügü'nde serbest bırakılarak, İstanbul'dan kaçmasına göz yumulan kişilerden birisi de Süvari Binbaşısı Tolcalı Süleyman Beydir. İstanbul Polis Müdürü Hasan Tahsin Bey, suikast tertibi içinde bulunduğu gerekçesiyle tutuklanan Tolcalı Süleyman Beyi serbest bırakmıştı. Bu olayı Ertürk'un hatıralarından öğrenmekteyiz: $\mathrm{Bu}$ olayla ilgili Ertürk şunları anlatmaktadır:

"Her ikimizi Polis Müdür-i Umumîsi Kalkandelenli Hasan Tahsin mütebessim bir çehre ile karşılamış ve:

“-Geçmiş olsun efendiler!" demişti., "hayatta siyasetle uğraşanların başına her zaman böyle hallerin gelmesi mukadderdir! Biraz evvel çok sevdiğim bir arkadaş olan süvari binbaşısı Tolcalı Süleyman Beyi de Damad Ferid Paşa'ya suikasd tertip etmekle meşgul diye ihbar ettiklerinde tevkif ettirmiştim. Fakat bu çok sevdiğim arkadaşı, işgal kuvvetlerine teslim etmeğe bir türlü gönlüm razı olmadığından firarını temin ettim....SŞimdi $O$ İstanbul'dan kaçmış bulunuyor."

Damat Ferit Paşaya suikast girişiminde bulunmak suçuyla yakalananlar, önce İstanbul Polis Müdürlüğü'nde sorgulanıyorlardı. Sorgulamaları bizzat İstanbul Polis Müdürü Hasan Tahsin Bey yapıyordu. Sorgulama bazen günlerce sürebiliyordu. Sorgulama esnasında şiddetli tazyik ve ağır işkenceler yapılıyordu. Sorgulaması tamamlananların Merkez Komutanlığına götürülüyorlar ve buradan da Adliye tevkifhanesine yollanıyorlard ${ }^{78}$. Suikast sanıkları burada, sadece tepesindeki cam

${ }^{76}$ Ertürk, (Nemrut) Mustafa Paşa ile yaptığı bu görüşmede, paşanın zamanında Teşkilât-1 Mahsusa' Cemiyeti'ne girdiğini ve bu konuda kendisinin rolünün bulunduğunu anlatmış, kendisine maaş verilmesi ve ailesinin erzakının temin edilmesini de kendisinin sağladığını belirtmişti. Yani kısaca Nemrut Mustafa Paşanın da bir zamanlar Teşkilât-1 Mahsusa elemanı olduğunu bildiğini, ellerinde bununla ilgili dokumanlar bulunduğunu söyleyerek, Divan-1 Harb başkanını üstü kapalı tehdit etmişti. Bkz. Ertürk, Iki Devrin Perde Arkast, s. 337-351.

${ }^{n}$ Ertürk, İki Devrin Perde Arkasi, s.339. Suikast davasından tutuklananlardan birisi olan Harbiye Nezaretine merbût Esliha ve Mühimmat Muayene-Tecrübe Hey'eti Esliha-i Hafife Şubesi ve Piyade Talim ve Terbiye Encümeni Azası Piyade Binbaşı Cemal Bey hatıralarında Tolçalı Süleyman Beyin kaçışıla ile ilgili olarak şu bilgiyi veriyor.

"Yine bu sıralarda İngilizler ve Ferit Paşa hükkümeti bir çok tevkifler yapıyor ve Tolçalı Süleyman Beyi tevkif etmek için arıyorlardı. Bir gece Süleyman Bey evime geldi. Hazırlanmış ve kaçıyordu. Mumaileyhe bir filinta ile miktar-1 kâfi fișek verdim. Yenikapı civarına kadar gittik. Bir motorla Bursa cihetine hareket etti ve gitti." Bkz. General Cemal Karabekir, Maçka Silâhhanesi Hatıraları (İstiklâl Harbi Kahramanları), Yay. Haz. Aykut Kazancıgil, Nehir Yay., İstanbul 1991, s.74.

${ }^{78}$ Suikast davası sanı̆̆ı olarak tutuklanan Binbaşı Cemal Bey de tutuklanışını şöyle anlatıyor: "Bir Ramazan gecesi sivil olarak Şehzadebaşı'nda dolaşırken, polisler, komiserler ve inzibat memurlanı tarafından tevkîf edildim, Evvela Merkez Komutanlığına, sonra Polis 
pencereden 1şı ve hava alan idam mahkumlarına mahsus hücrelere ayrı ayrı konulmuşlardı. Hücrelerin durumunu tasvir eden Ertürk "Geceleri bu idam hücrelerinde en ufak bir ışık yakılmadığı için, zifiri karanlıkta bostan kuyusu gibi bu korkunç ve rutubetli taş odalarda mukadderatımızı beklemeğe başlamışık" demektedir ${ }^{79}$

Suikast ile ilgili yargılamaları devam ettiği günlerde "Yıldız yağmagerliği ve Kuva-yı Milliye'ye yardım etmek" suçlarıyla itham edilerek (Nemrut) Mustafa Paşa Divan-1 Harb-i Örfisi'nde yargılanan eski Dahiliye Nâzırlarından Ebubekir Hazım (Tepeyran) Bey, kendisinin de bir süre kaldığı Adliye Tevkifhanesini şöyle tasvir etmektedir:

\footnotetext{
"Sanki "taş localar" denilen bu münferit zindanlarda tâzip olunmama razı değil gibi açılmak istemedi.(...)Birkaç adım gittikten sonra sola döndük. Burası ancak bir metre kadar genişlikte uzun bir koridor idi. Sol tarafta sıralanan münferit hücrelerden kırmızıya boyanmış olan kapıst üzerinde beyaz boya ile(kapalı) yazılmış hücrenin önünde durdu(...)
}

Hayli kalın tahtadan yapılmış olan bu küçük kapının üst kısmında $15 \times 20$ santimetre mesahasındaki delikten başka dünya ile münasebeti muhafaza edecek bir şey yoktu. Taşla, tuğla ile yapılıp her tarafı aynı renkte çimento ile sıvanmış olan bu dışarıya bakmak mümkün olmayacak derecede yükseklikteki küçük penceresinden biraz ziya, biraz hava girmese insan diridiri, taşdan oyulmuş bir lahde konulmuş olduğunu zannedebilirdi.

İ̧inde, oturacak, yahut yatılacak bir hasır eskisi bile bulunmayan bu pek çıplek zindanda bir saat kadar ayakta durarak ve yoruldukça bir köşeye çömerek..." ${ }^{80}$

\section{SUIKASTÇILARIN YARGILANMASI}

İstanbul Polis Müdürlüğü'nce tutuklanan suikast davası sanıkları, sorguları yapıldıktan sonra yargılanmak üzere Divan-1 Harb-i Örfi'ye sevk edilmişlerdi. Bu davaya bakmak üzere İstanbul Birinci Divan-1 Harb-i Örfisi görevlendirilmişti. Divan-1 Harbin başkanlığını yürüten Mustafa Paşa dolayısıyla, bu mahkemeye(Nemrut) Mustafa Paşa Divan-1 Harb-i Örfisi de denilmekteydi ${ }^{81}$. Divan-1 Harb-i Örfi'nin kararlarına yaptığı etkiden dolayı

Müdüriyeti'nin emrindeki Şahinpaşa Oteline, ertesi gün Askeri Tevkifhaneye sevk edildim" Bkz. Karabekir, age., s.74.

${ }^{79}$ Ertürk, Iki Devrin Perde Arkasi, s.344.

${ }^{80}$ Ebubekir Hazım Tepeyran, Zalimane Bir Idam Hükmü, Milli Mecmua Basımevi, İstanbul 1946. s.139-140.

${ }^{81}$ Daha önce görev yaptığı Divan-1 Harb-i Örfi'lerde sergilediği tavır ve mahkemenin kararlarını etkilemesinden dolayı onun başkanlığını yaptığı bu son mahkemeye "Nemrut Mustafa Paşa Divan-1 Harb-i" adı da verilmişti. Bkz. Necdet Bilgi, Ermeni Tehciri ve 
halk arasında "Nemrut" lakabı ile anıldığı gibi, "Kürt Mustafa Paşa" olarak da anılmaktaydı. Başkanlığını yaptığı bu mahkeme, Kuva-yı Milliye ileri gelenleri hakkında gıyaplarında arka arkaya "idam" kararları vermesiyle tanınmışt ${ }^{82}$. Yine Urfa Mutasarrıfı Nusret Beyin ve eski Dahiliye Nâzırlarından Ebubekir Hazım Beyin haklarında da idam cezaları bu mahkeme tarafından verilmişti.

Suikastçıları yargılayacak olan I.Divan-1 Harb-i Örfi'nin Başkanı Nemrut Mustafa Paşaydı. Piyade Kaymakamlarından Fettah, Süvari Miralaylarından Recep, Süvari Miralaylarından Ferhat Beyler ve Erkan-1 Harb Mirlivalarından Recep Paşa ise mahkemenin diğer üyeleriydiler ${ }^{83}$.

Suikast davasından göz altına alınanların mahkemesine hemen başlamıştı. Nitekim tutuklu sanıklar, Adliye Tevkifhanesinden Divan-1 Harbe götürülmüş ve sanıkların yargılanmasına başlanılmıştı ${ }^{84}$. Sonraki günlerde sanıkların mahkemedeki yargılamaları devam etti. Ancak basında çıkan haberlerden bu davanın çok uzun sürmeyeceği ve kısa zamanda sonuçlanacă̆1 anlaşıllyordu. 3 Haziran tarihli bir gazetede "Mevkûflar Divan-1 Harbde" başlığıyla çıkan haberde "Sadrazam Damad Ferid Paşa Hazretleriyle rüfekây-ı içtihâdlarına suikast tertîb eylemiş bulunan çeteciler dün üç buçukda arabalarla mahfûzen hapishane-i umûmiyeden Divan-l Harb-ı Örfi'ye isâl edilerek muhakemelerine devam edilmişdir. Suikast faillerinin muhakemesi pek uzun sürmeyecek olub hatta evvelki gün merkûminin icra-yı muhakemeleri geceleyin on bire kadar devam etmişdir. İstidlâl edildiğine nazaran suikastçıların daha bir takım şerîk-i cürümleri mevcûddur" deniliyordu ${ }^{85}$.

10 Haziran tarihli Alemdar'da "Suikastçıların Muhakemesi" başlığıyla çıkan haberde "Suikast mürettiblerinin muhakemesine devam edilmekde ve birkaç güne kadar muhakemelerin hitam edeceği muhakkak görülmekte-

Boğazlıyan Kaymakamı Mehmet Kemal Beyin Yargılanması, Köksav Yay., Ankara 1999, s.133, Dipnot 240.

${ }^{82}$ Bu idam kararlarından ilki; Mustafa Kemal Paşa, Kara Vasıf Bey, Ali Fuat Paşa, Alfred Rüstem Bey, Dr. Adnan Adıvar Bey ve Halide Edip Hanım hakkında çıkarılmıştır. İdam kararı ile ilgili İrade-i Seniye için Bkz.. Takvim-i Vekâyi, 27 Mayıs 1336(1920), Nr: 3864. Yine aynı mahkeme tarafından ikinci olarak Kavaklı Fevzi Paşa hakkında verilmiştir. Bu karar içinde Bkz.. Takvim-i Vekâyi, 30 Mayıs 1336(1920), Nr: 3866.; Yine aynı mahkemece üçüncü olarak Miralay Selahaddin, Miralay Fahreddin, Miralay İsmet, Miralay Bekir Sami ve Miralay Abbas Hilmi Beyler, Yusuf İzzet ve İsmail Fazıl Paşalar ve mebuslardan Celaleddin Arif, Bekir Sami, Hamdullah Suphi, Cami, Hakkı Behiç ve Rıza Nur ve Yusuf Kemal Beyler ile Eskişehir Mutasarrıfı Fatin Bey ve Müftülerden Mustafa Fehmi ve Mehmet Rifat Efendiler hakkında verilmiştir. Bkz.. Takvim-i Vekâyi, 21 Haziran 1336(1920), Nr: 3883.

${ }^{83}$ BOA, DUIT, Nr.79/5-117.;

${ }^{84}$ Vakit gazetesinde çıkan bir haberde "zanlıların mahkemelerine Mustafa Paşa'nın başkanlık ettiği ve Divan-1 Harbi Örfi'de evvelki gün saat 11'de başlandı̆̆ı” belirtiliyordu. Vakit, 3 Haziran 1336(1920), Nr. 907

${ }^{85}$ Alemdar, 3 Haziran 1336(1920)i Nr.530/2830. 
dir" ${ }^{\prime 86}$ denilmekteydi. Gerçekten de bu dava pek uzun sürmemiş üç dört gün daha devam etmişti. Nihayet mahkeme 9 Haziran tarihinde kararını vermişti ${ }^{87}$

Damat Ferit Paşa, Ali Kemal ve Sait Molla'ya suikast teşebbüsünde bulunmak ve İstanbul'da geniş çaplı bir gizli teşkilât kurmak suçlarından, İstanbul Birinci Divan-1 Harb-i Örfisi'nde yargılananlar hakkındaki hüküm ve gerekçeli karar 11 Haziran tarihinde Padişah Mehmet Vahdettin tarafindan onanmıs ${ }^{88}$ ve bu kararlar ilgili İrade-i Seniyye de 13 Haziran tarihli Takvim-i Vekâyi' de yayınlanmıştı ${ }^{89}$.

Divan-1 Harb-i Örfi, bu davada, yakalanarak tutuklanan on altı sanık ile yakalanmamış, ancak bu davayla ilgili olduklarına hükmedilmiş on beş sanık da dahil olmak üzere toplam otuz bir sanığı yargılamıştır.

Yargılama sürecinde Divan-1 Harb-i Örfi, bazı sanıklar hakkında iddia edilen suçlarla ilgili aydınlatılması ve açıklanması gereken cihetler olduğu, bu nedenle daha etraflı araştırma yapıldıktan sonra kesin bir hükme varılacağı belirtilerek, bu sanıklarla ilgili yargılamanın ayrılmasına karar vermişti. Yargılamaları suikast davasının dışına çıkartılan bu sanıklar "Hafız Nuri, Yüzbaşı Hasan Tahsin, Yüzbaşı Ahmet Kemal, Mülâzım-1 evvel Rüşdü, Yüzbaşı İhsan, Çeteci Çerkes Eşref'in biraderi Ahmed Yüzbaşı, Hasan Adlî Efendi, Miralaylıktan mütekaid Aziz Samih, firari Yüzbaşı Ali Rıza, Binbaşı Osman, Resneli Osman Fehmi, Yüzbaşı İzzet Canbolat, Dava Vekili Baha Bey" olmak üzere 13 kișiydi $^{90}$. Konuyla ilgili olarak Alemdar'da çıkan bir haberde "Merkûmun dünkü muhakemelerinde inkişâf eden bazı nukat hakkında tamik-i tahkikât lüzûmu hasıl olmasına mebni suikastçılara aid muhakemenin sekiz on gün daha devam etmesi zarureti hasll olmuştur" deniliyordu ${ }^{91}$.

Suikast davasından ayrı tutularak, haklarında daha ayrıntılı araştırma yapılması uygun görülen bu kişileri ilgilendiren bir yazışma ve listeden bahsetmek istiyoruz. 20 Mayıs 1920'de İstanbul Polis Müdürü Umumisi Hasan Tahsin Bey tarafından Adliye Nezâretine bir yazı gönderilerek "Harp sırasında işledikleri ve işlettikleri cinayetlere ara vermeksizin isyanlarını günden güne hızlandırmak suretiyle iç emniyeti karmakarışı ve bütün doğunun siyasî ve insâni hayatına suikast eden adları ilişik listede yazılı kimseler, hâlen cinayet ortakları bulunan isyan ve fesâd erbâbı ile faaliyet ve haberleşmelerde bulundukları sabit olduğundan bozulan sükûn ve asâyişin geri gelmesinin ve devamının sağlanması bu kişilerin bir dakika

${ }^{86}$ Alemdar, 10 Haziran 1336(1920), Nr.537/2837..

${ }^{87}$ BOA, DUIT, Nr.79/5-117.

${ }^{88}$ Taner Akçam, "Divan-ı Harb-i Örfi'lerin Kurulması-İstanbul Yargılamaları-" Tarih ve Toplum, Sayı: 13,(Mayıs 1995), s.52, dipnot: 25.

${ }^{89}$ Takvim-i Vekâyi, 12 Haziran 1336(1920), Nr.3878.

${ }^{90}$ BOA, DUIT, Nr.79/5-117.

${ }^{91}$ Alemdar, 11 Haziran 1336(1920), Nr. 539/2839. 
evvel yargılanıp kanunî cezalarının icrasına bağlı bulunduğu beyân olunur" denilmiş ve tutuklanması istenilen kişi isimlerinin bulunduğu "otuz dört isimli bir ve elli dört isimli iki liste" bu yazıya eklenmişti. Adliye Nezâretince, Askerî Adliye Dairesi'ne ve oradan da Harbiye Nezâretine gönderilen bu yazı ve eki olan isim listeleri, bilahare Harbiye Nezâreti tarafından İstanbul Birinci Divan-1 Harb-i Örfi'ye gönderilmişti. ${ }^{92}$

İşte İstanbul Polis Müdürü Hasan Tahsin Beyin hazırladığı bu listede, suikast davası ile ilişkilendirilerek tutuklanan ya da yakalanamayıp aranan isimler de mevcuttu. Bunlar arasında; "Piyade Binbaşısı Resneli Osman Bey, İsmail Canbulad Beyin kardeși Süvari Binbaşısı İzzet Bey, Piyade Yüzbaşısı Ali Rıza Bey, Piyade Yüzbaşısı İsmail Hakkı Bey, Piyade Yüzbaşısı İhsan Bey, Piyade Yüzbaşısı Hasan Tahsin Efendi, Kurmay Albay Aziz Sami Bey, Köprülülü Yüzbaşı Hasan Adlî Bey” vardı. Bu isimlerin bulunduğu listeye düşülen bir notta "Mustafa Kemal'in başkanlığında bütün Anadolu'da fesad çıkaranların kışkırtıcı ve tahrikçisi bulunan ve bütün olaylara fiilen karışıp daima kendi çlkarları için ahalinin fikirlerini her surette zehirleyen rütbece küçük, fakat faciaları yaratma bakımından suçları pek büyük olan şahıslar" denilmekteydi ${ }^{93}$.

Bu yazı ve listedeki isimlerden anlaşıldı ğına göre, İstanbul Polis Müdürlüğü, faaliyetlerini öteden beri takip ettiği bu isimleri önce suikast davası ile ilişkilendirmeye çalışmış, bilahare yargılama sürecinde bu kişiler suikast davası çerçevesinden çıkartılarak "İstanbul'da vasi teşkilât-1 hafiyede bulunmak" suçlaması ile yargılanmaya devam edilmişlerdi.

Yapılan yargılama sonucu Damat Ferit Paşa, Ali Kemal ve Sait Molla'ya suikast girişimi, sanıklardan Dramalı Rıza, Mehmet Ali ve Tevfik Beylerin birbirleri doğrulayan açıklamaları ile kesinlik kazanmıştı. Sanıkların üzerinde ve gösterdikleri yerlerde bulunan silah, yeterli sayıda mermi ve bombalar gibi suç aletleri de suikast girişiminin varlığını teyit eden kuvvetli delillerdi. Ayrıca suikast ile ilgili her türlü hazırlıkların tamamlandığını belirten ve suikastçılara ödenecek paranın gönderilmesini isteyen mektup başta olmak üzere, ele geçen evrak ve bazı belgelerde suikastın bir tertibe dayandı̆̆ını ortaya koymaktaydı ${ }^{94}$.

Sanıkların açıklama ve itirafları, ele geçen suç aletleri ile evrak ve benzeri yazışmalar gibi delillere dayanan Divan-1 Harb-i Örfi Heyeti, suçun kesinlik kazanmış olduğu kanaatine varmış ve bu davadan yargılanan sanıkları değişik suçlamalarla, değişik cezalara çarptırmıştı. Buna göre;

\footnotetext{
${ }^{92}$ Midhat Sertoğlu, "Millî Mücadeleye Yardım Ettikleri İçin Cezalandırılmak İstenenlere Dair Yayınlanmamış Belgeler”, Hayat Tarih Mecmuası, Yıl:14, C.1, Sayı:2, (1 Şubat 1978), İstanbul, s. 47.

${ }^{93}$ Sertoğlu, agm., s. 48 .

${ }^{94}$ BOA, DUIT, Nr.79/5-117.
} 
Bekir Sami, Hacim, Remzi ve Nuri Beyler suikastın düzenleyicileri teşvikçileriydi. Armutlulu Mehmet Kapdan, suikastçıların haberleşmeleri ve ulaşımlarını sağlamıştı. Tutuklu olan Dramalı Rıza, Halil İbrahim, Tevfik(Sükûti), Mehmet Ali ile firarilerden Binbaşı İhsan, Binbaşı İsmail Hakkı, Tolcalı Süleyman, Ahmet Halim, İbrahim Ago Beylerle Bursa Yenişehirden Hasan ve Bursalı Çoban İsmail fesat heyetince İstanbul'da gerçekleştirilecek ihtilal hareketini hazırlamak ve Damat Ferit Ali Kemal ile Sait Molla hakkında suikasta girişmek, bunun için silah ve bombalar hazırlamakla suçlanıyorlard ${ }^{95}$.

Mahkeme yukarıda verdiğimiz suçları işlemiş olan sanıkları "Mülkiye Ceza Kanunname-i Hümayûnun" ilgili maddelerine dayanarak; "birden fazla kişiye cinayet düzenlemek, birden fazla kişi bir araya gelerek cinayet işlemek, birlikte cinayet işlemek amacıyla suç ortaklı̆̆ 1 yapmak, devlete ve hükûmete karşı isyan etmek ve halkı da bu isyana tahrik ve teşvik etmek, halkın arasına fesat ve nifak sokarak birbirine karşı silahlandırarak birbirlerini öldürmeye tahrik ve teşvik etmek, ülkenin bazı bölgelerinde halkın malını zorla almak ve yağmalamak, köy ve kasabaları yakıp yıkarak katliam yapmak, bir fesat hareketi veya isyan için hazırlıklar yapmak, dinamit ve bomba imal etmek ya da hazırlamak, isyancılarla birlik olmak gibi" suçlardan dolayı idama çarptırmıştır.

Binbaşı Adil, Binbaşı Raşid Beyler ile Yüzbaşı Bican Beyefendi ise suikast girişimine katılıp katılmadıkları tam anlaşılmamakla birlikte, suikastın yapılacağını bildikleri halde bunu hukûmet kuvvetlerine bildirmemekle suçlanmaktaydılar.

Bu kişileri Divan-1 Harb-i Örfi, Mülkiye Ceza Kanunname-i Hümayûnun ilgili maddesi olan "Suikast girişiminde kullanılacak bomba gibi savaş aletlerinin hazırlandığını bildikleri halde bunları hükûmet kuvvetlerine hiçbir mazeretleri olmaksızın bildirmedikleri" için on sene geçici kürek cezasına çarptırd.

Binbaşı Cemal Bey, suikast girişimine katılmamakla birlikte, Anadolu'daki asilere silah ve cephane sağlamakla suçlanmış ve on sene geçici kürek cezasına çarptırılmıştı. ${ }^{96}$.

Suikastın tetikçisi olan Dramalı Rıza Bey ise, suikast teşebbüsünü hükûmet kuvvetlerine ihbar ederek, suikastın düzenleyicileri ve teşvikçilerinin yakalanmasını sağladığı için "suikast" suçunun öngördüğü cezadan muaf tutulmuştu. Ancak kendisi fitne-i bagiye olarak nitelendirilen Kuva-yı Milliye'nin ileri gelenlerinden olduğu ve aşağıdaki suçları işediği için yine Mülkiye Ceza Kanunnâme-i Hümayunu'nun 45. Maddesinin 1. fıkrası ve 55. Maddesinin 4. fıkrasına ve 56. Maddesine göre idam cezasına

${ }^{95}$ BOA, DUIT, Nr.79/5-117.

${ }^{96}$ BOA, DUIT, Nr.79/5-117. 
çarptırılmıştı. Dramalı Rıza Beyin idamına neden olarak gösterilen ve işledi kabul edilen suçları şöyleydi:

\begin{abstract}
“...a'vâne-i hunisi ile birlikte Biga'ya gider gitmez yirmi dört saat zarfinda askere gelmeyenlerin idâm edilecekleri tehdîdile ahaliden cebren asker cem'ine ve askere elverişli olmayanlardan yüz lira bedel-i nakdi almak ve tevkîf ve işkence itmek sûretile yüz yirmi bin lirayı mütecaviz para ahz ü gasbına ve ötekinin berikinin kızlarunu alub mest-i efrâdına virmek ve zahîre anbarlarını kırarak mevcut zahireyi ve ahalinin hayvanatını cebren gasb idüp kendi karargahına taşımak ve ahîren dahi avane-i leimânesile beraber Kirmasti'yi basıp kaza mal sanduğundan ve duyân-ı umûmiye ve reji idaresinde mevcut parayı gasb ve derceb etmek ve Biga müsademesi neticesinde mecbûr-i firâr olduğu esnada civar kura ahalisinden on iki masumu ve kendi maiyyetinden dahi bazısını katl ve idam eylemek gibi medeniyet ve insaniyetin tasavvurundan bile hicabedeceği mezalim ve fezayihi ve Biga Mevkii Kumandanı Hafız Mehmet Beyi terk-i me'mûriyete icbâra cür'et eylediği ve kuva-yt bagiyenin en hûnrîz rüesasından olub bil'âhire Biga hadisesinde maktûl rüesadan olan Hamdi ile birlikte Akbaş nâm-ı mevkiye geçerek orada bulunan muhafız Ingiliz ve Fransız askerlerini bağlatdırarak düvel-i itilâfiyenin nezâreti altında bulunan esliha ve cebhaneyi ahz ü gasb ile hükûmetin başına büyük bir gaile ihdasına sebebiyet verdiği"
\end{abstract}

Divân-1 Harb-i Örfi, Bursa'da bulunan Miralay Bekir Sami Bey için, daha önce gıyabında "idam" cezası verildiğini dikkate alarak, onun hakkında tekrar bir ceza tayin edilmesine gerek olmadığına karar vermişti ${ }^{97}$.

Dava sonuçlanmış ve Nemrut Mustafa Paşa, böyle bir fırsattan istifade ederek Kuva-yı Milliye'ye önemli hizmetler yapmış olan bir çok şahsı, ayrıntılı bir inceleme yapmaksızın, birkaç gün süren yargılamalar sonucunda idam ve 10 'ar sene kürek cezasına çarptırmıştı. Mahkemenin gerekçeli kararına göre bu davadan idam cezası alan sanıklar "Bekir Sami, Hacim, Remzi ve Nuri Beyler, Armutlulu Mehmet Kapdan, Dramalı Rıza, Halil İbrahim, Tevfik(Sukuti), Mehmet Ali Beyler, Binbaşı İhsan, Binbaşı İsmail Hakkl, Tolcalt Süleyman, Ahmet Halim, İbrahim Ago Beylerle Bursa Yenişehirden Hasan ve Bursalı Çoban İsmail" olmak üzere on altı kişiydi. Mahkemenin verdiği karara göre 10 sene kürek cezasına çarptırılan sanıklar ise "Binbaşı Adil, Binbaşı Rașid, Binbașı Cemal Beyler ile Yüzbaşı Bican Beyefendi” olmak üzere dört kişiydi.

Mahkeme ayrıca mesleği askerlik olanların, bu meslekten çıkarılmasına ve halen firari olan sanıklardan Hacîm, Remzi, Nuri, Tolcalı Süleyman Beyler ile Binbaşı İhsan, Binbaşı İsmail Hakkı, Ahmet Halim, Mehmet

${ }^{97}$ Miralay Bekir Sami bey hakkında verilen idam karanı için bkz. Takvim-i Vekâyi, 21 Haziran 1336(1920), Nr: 3883. 
Kaptan ve Hasan ve İsmail ve İbrahim Ago'nun mallarının haczedilerek, usulüne göre idare ettirilmesine de karar vermişti. ${ }^{98}$

Mahkemenin verdiği bu kararlar, tutuklu olan sanıkların yüzüne okunmuş, firarda olan sanıklar hakkında da gıyaplarında okunmuştu. Mahkeme heyeti, sanıklara verdiği bütün bu cezaları oy birliği ile kararlaştırmıştı.

Diğer taraftan mahkemeleri tefrik edilenler hakkında sonraki günlerde basında haberler çıkmaya başlamıştı. 22 Haziran tarihli Alemdar gazetesinde "Suikastçılar" başlığıyla çıkan bir haberde "Suikastçılardan muhakemesi tefrîk edilmiş bulunanlara aid tahkikâtda derdest-i hitam olmağla, merkûmun hakkında pek yakında Bir Numaralu Divan-ı Harb'çe itayı hüküm olunacaktır" deniliyordu. ${ }^{99}$

\section{SUIKAST SANIKLARININ IDDAMI}

Divan-1 Harb-i Örfi, Damat Ferit Paşa, Ali Kemal ve Sait Molla’ya suikast girişiminde bulunmak ve İstanbul'da geniş çaplı bir gizli teşkilât kurmak suçlarıyla yargıladığı sanıklardan on altısına idam cezası vermişti. Ancak, önceki bölümlerde belirttiğimiz gibi, sanıklardan bir kısmı yakalanarak tutuklanmış, bir kısmı ise kaçarak ya da gizlenerek yakalanmaktan kurtulmuşlardı. Fakat kaçan ve gizlenen sanıklar da mahkemede yargılanmışlar ve bunlar hakkında verilen karar gıyaplarında olmuştu.

İşte Divan-ı Harb-i Örfi'de yargılanarak "idam” cezası ile cezalandırılanlardan sadece dördü tutuklu bulunuyordu. Bunlardan ikisi suikastın tetikçileri olarak Bursa'dan İstanbul'a gelmiş olan Dramalı Rıza ile Bahriye Yüzbaşısı Halil İbrahim Beylerdi. Diğer ikisi ise Karakol Cemiyeti'nin İstanbul'daki faal elemanlarından Maliye Nezâreti Muhassasat-1 Zâtiye ve Mâ'zulin Şubesi mümeyyiz-i evveli Tevfik Bey ile Üsküdar Belediyesinin Doğancılar mevkii memuru Mehmet Ali Beydi.

Damat Ferid Paşa Hükûmeti, suikast davasından yargılanarak idam cezasına çarptırılan ve o sıra Adliye Tevkifhanesinde bulunan Dramalı Rıza Bey ve diğerlerinin cezasını hemen uygulatmak istiyordu. Bu hem İstanbul Hükûmeti'nin Anadolu'da otoritesini hiçe sayan Kuva-yı Milliye Hareketine hem de İstanbul'da bulunan ve millî teşkilâta yardım edenlere ve aynı zamanda İttihatçıların kurmuş oldukları gizli teşkilât ve kuruluşlara ders olacak, gözdağı verilecekti.

Nitekim İstanbul Birinci Divan-1 Harbi Örfisi'nin suikast sanıkları hakkında verdiği hüküm, 11 Haziran da Padişah tarafından tasdik edilmiş ve bununla ilgili "İ̉rade-i Seniyye" 12 Haziran 1920 günlü Takvim-i Vekâyi'de

${ }^{98}$ BOA, DUIT, Nr.79/5-117.

${ }^{99}$ Alemdar, 22 Haziran 1336(1920) Nr.549/2849. 
yayınlanmıştır $^{100}$. Artık idamların yapılması için gerekli olan süreç tamamlanmıştı. Bu kararın yayınlandığı gün sabah erken saatlerde suikast davasından idama mahkûm edilen dört kişi "asılarak" idam edileceklerdi ${ }^{101}$.

İdamlar Beyazıt meydanında yapılacakt ${ }^{102}$. Bunun için oraya dört darağacı kurulmuştu. İttihatçıların bu dört idam mahkumunu son anda darağaçlarının altından kapıp kaçıracaklarına ilişkin bir şayia çıkmıştı. Bu şayianın Hükûmeti ve İstanbul Polis Müdüriyetini derin bir endişeye sevk ettiği söyleniyordu ${ }^{103}$. Bu nedenle Hükûmet, herhangi bir hadise ile karşılaşmamak için idâmları sabah çok erken saatte icra etme kararını almıştı.

Dramalı Rıza Bey ve diğer üç idâm mahkumu, 12 Haziran sabahının alaca karanlığında nezaret altında bulundukları Adliye Tevkifhanesi'nden alınarak arabalarla Merkez Komutanlığına götürüldüler. Burada mahkûmlar için dini merasim yapılmış ve kendilerine son arzuları sorulmuştu.

Nezaret altında bulunduğu günlerde, çok önemli ifşaatta bulunduğu ve ayrıntılı bir suçlu listesi verdiği ileri sürülen Dramalı Rıza Bey, son ana kadar kendisine vaat edilen af kararını beklemiş, ancak bunun gerçekleşmediğini görmüştü. Kendisi bu durum karşısında en küçük bir telaş ve korku eseri göstermemiş ve derin bir sükunet ve feragat içinde son arzu ve vasiyetini bildirmişti $i^{104}$.

Dramalı Rıza Beyin son arzu ve vasiyeti şöyleydi:

\begin{abstract}
"Üzerinde çıkan yedi lira ve üç çeyrekle bileğindeki kol saati ve Polis Müdürlüğ̈̈'nde emanet bulunan 270 küsur lirast, felaket ve ölüm yoldaşı Bahriye Yüzbaşısı Halil İbrahim Beyin dul kalan ailesine verilecekti."
\end{abstract}

Bu vasiyet, suikast davasında Dramalı Rıza Beyin, para meselesinden dolayı arkadaşları ile ve özellikle Bahriye Yüzbaşısı Halil İbrahim Bey ile anlaşmazlığa düştüğü ve bu nedenden dolayı Dramalı Rıza Beyin, bütün arkadaşlarını ele verdiği iddiasına verilen en güzel bir cevap oluyordu.

${ }^{100}$ Takvim-i Vekâyi, 12 Haziran 1336(1920), Nr.3878. Ayrıca bkz. EK. II.

${ }^{101} 13$ Haziran tarihli İstanbul gazetelerinde büyük başlıklarla bu idâm haberi duyuruluyor, aynı zamanda Divan-ı Harb-i Örfi'nin gerekçeli karanı da yayınlanıyordu. Bu gerekçeli karar bazı gazetelerde iki sayfayı dolduracak kadar yer kaplamıştı. Vakit gazetesi "Suikastçılardan Dört Kişi Dün Sabah Salben İdam Olundu” başlığıyla haberini duyurmaktaydı. Vakit, 13 Haziran 1336(1920), Nr:917. Alemdar gazetesi ise birinci sayfada "Adaletin Heybetnümûn Bir Tecellisi”başlığıyla idamı duyuruyordu. Alemdar, 13 Haziran 1336(1920), Nr.540/2840.

${ }^{102}$ İbnülemin Mahmut Kemal suikast sanıklarının "1338 remazanının 24 üncü Cuma ertesi günü sabahı Beyazıd meydanında salb olunduklarını” söylemektedir. Bkz., İbnülemin Mahmut Kemal İnal, Son Sadrazamlar, C. 4, 3. Bask1, Dergah Yay. 1982., s.2058.

${ }^{103}$ Göztepe, “Nemrut Mustafa'nın Astığı Kuva-yı Milliyeciler”, Dün ve Bugün, s.27.

${ }^{104}$ Göztepe, "Yaşasın İttihat ve Terakki !”, Dün ve Bugün, s.20. 
Bahriye Yüzbaşısı Halil İbrahim Bey ise, kolundaki saatinden başka bir serveti olmadığını söylemiş ve vasiyet olarak bu saatin bir hatıra olarak ailesine verilmesini istemişti. İdam öncesi Yüzbaşı Halil İbrahim Bey kirli kıyafetle idam ve teşhir edilmeyi istememiş, Polis Müdürlüğü'nde bulunan temiz çamaşırlarını ve fanilasını getirterek onları giymişti ${ }^{105}$.

Merkez Komutanlığı'ndaki dini merasim ve son arzu ve vasiyetlerin bildirilmesi işleminin tamamlanmasından sonra sıra idamlara gelmişti. İdam mahkumlarına beyaz gömlekler giydirilmiş, göğüslerine yaftaları takılmış ve elleri arkalarına kelepçelenerek süngülü çok sayıda muhafızları arasında, darağaçlarının başına getirilmişlerdi. Dramalı Rıza Beyin göğsüne takılan yaftada şu yazılar okunuyordu:

\footnotetext{
“Anadolu'daki Kuva-yı Milliye nam heyet-i fesadiyenin rüesasından olub bir çok cinayât-ı aẑ̀me irtikap etmesinden dolayı Birinci Divan-l Harb-i Örfi tarafindan bi'l-muhakeme idamına karar verilen ve idamı irade-i seniyye-i padişahiye iktiran eden Dramalı Rıza Bey" 106
}

Önce Bahriye Yüzbaşısı Halil İbrahim Bey asılmıştı. Büyük bir heyecan ve telaş içerisinde olan Yüzbaşı Halil İbrahim Bey asılmaya giderken son derece perişan bir durumdaydı. Muhafızları tarafından adeta sürüklenerek en baştaki darağacın başına getirilmişti. Daracığın yanına gelindiğinde ise yere yı̆̆̊̆lıp kalmış, boylu boyuna kaldırımın üzerine uzanmıştı. ${ }^{107}$

Halil İbrahim Beyin idamının ardından sıra Dramalı Rıza Beye gelmişti. Dramalı Rıza Bey, cesurdu ve uzun yıllar komitacılık yapmıştı. O yüzden asabına son derece hakim ve fütursuz bir halde idi. Biraz önce asılan kader arkadaşı Halil İbrahim'in darağacında sallanan ve henüz soğumamış olan cesedinin önünden pervasızca geçerek kendi asılacağı darağacına doğru yürüdü. $\mathrm{Bu}$ arada kendi kendine ulu orta küfürler söylemiş ve hatta mensup olduğu İttihatçılara da "kahrolsunlar" demişti. Dramalı Rıza Bey hızlı adımlarla darağacın altına gelmiş, muhafızların ve idamı yapacak olan cellat çingenenin yardımına gerek olmaksızın iskemlenin üzerine sıçrayarak çıkmışt1 ${ }^{108}$

Dramalı Rıza Bey iskemlenin üzerine çıktıktan sonra başını kaldırmış ve etrafını saran süngülü muhafızlara hitaben "Askerler, vatanı düşmana satan hainler bizi düşman parası ile öldürüyorlar" diye haykırmıştı. Bu haykırış, muhafızları etkilemiş, bir çoğunda merhametle tereddüde benzeyen bir kararsızlık duygusu yaratmıştı. Dramalı Rıza Beyin bu haykırışının askerler üzerindeki etkisini gören bir Jandarma Miralayı koşarak gelmiş ve Dramalı Rıza'nın üzerine atılarak, elleri ile sıkı sıkı ağzını kapamıştı. Jandarma

${ }^{105}$ Göztepe, "Yaşasın İttihat ve Terakki !", Dün ve Bugün, s.20.

${ }^{106}$ Vakit, 13 Haziran 1336(1920), Nr:917. Ayrıca bkz. Göztepe, "Nemrut Mustafa'nın Astığı Kuva-yı Milliyeciler", Dün ve Bugün, s.27.

${ }^{107}$ Yaşasın İttihat ve Terakki !", Dün ve Bugün, s.20.

${ }^{108}$ Agm., s. 20. 
Miralayının "söyletmeyin, asın" diye bağırmasının ardından cellat çingene, ilmiği Dramalı Rıza Beyin boynuna geçirmiş ve üzerinde durduğu iskemleye bir tekme atarak, onu boşluğa sallandırmıştı

Daha sonra asılma sırası Mehmet Ali Beye gelmişti. Mehmet Ali Bey asılacağı daracığın başına geldiğinde ideal bir İttihatçı kimliği çizerek "Yaşasın İttihat ve Terakki Cemiyeti!" diyerek haykırmıştı. Bu haykırışının arkasından boynunu ipe uzatmış ve cellat da işini hemencecik yapıvermişti ${ }^{109}$.

En son asılma sırası Tevfik(Sükûti) Beye gelmişti kendinden önce üç kader arkadaşı asılmasına rağmen hiçbir telaş eseri göstermeden darağacın altındaki iskemleye çıkmış ve sakin bir şekilde cellâdın gelmesini beklemişti. Nitekim cellât çingene hiçbir direniş görmeden işini görmüştü ${ }^{110}$.

Suikast davası ile ilgili gerekçeli karar ve dört kişinin asılmasıyla ilgili haberler, 13 Haziran tarihli İstanbul gazetelerinin birinci ve ikinci sayfalarını boydan boya süslemişti. Vakit gazetesi "Suikastçılardan Dört Kişi Dün Sabah Salben İdam Olundu" başlığıyla verdiği ve iki sayfayı bulan haberinde, İrade-i Seniyye ile Divan-1 Harb-i Örfi'nin "Mazbata-i Hükmiyesi"nin tamamını vermişti ${ }^{111}$. Alemdar ise "Adaletin Heybetnümûn Bir Tecellisi” başlığıyla konuyu birinci sayfasında vermekte ve aynı başlığın altıda daha küçük puntolarla "Dört Canavar Şaki Dün Sabah Salben İdam Edildi" diyerek idam ile ilgili bilgiler vermekteydi ${ }^{112}$.

Refi Cevat da Alemdar'daki köşesinde "İdam" başlığıyla yazdığı yazıda "Adalette merhamet vardır. Bi-günâhı siyânet eder. Fakat bu merhamet canilerin cezasız kalmasını müstelzim olamaz. Dün salben idam edilenler defeci olsa bile- irtikâb eyledikleri cinayatın muhik bir cezasını görmüşlerdir. Adalete serfüru ederiz" diyerek idamların yapılmasını memnuniyetle karşıladığını yazmaktaydı ${ }^{113}$.

\section{SONUÇ}

Millî Mücadeleyi ve bu mücadelenin başındaki kişileri yok etmek amacıyla dördüncü defa iş başına gelen Damat Ferit Paşa, İngilizler ile Hürriyet ve İtilaf Fırkası, İngiliz Muhibleri, Askerî Nigehban ve Kızıl Hançerliler Cemiyetleri gibi Millî Mücadele aleyhtarı cemiyet ve kuruluşlarla tam bir işbirliğine girmişti.

Millî teşkilâtın ve mensuplarının ülke ve millet düşmanlığı yaptığını kabul edecek kadar hainane ve gafilane duygular içerisinde olan Damat Ferit

\footnotetext{
${ }^{109}$ Agm., s. 27 ,

${ }^{110}$ Aynt yer, s. 27.

II' Vakit, 13 Haziran 1336(1920), Nr. 917. Bkz. EK. III.

${ }^{112}$ Alemdar, 13 Haziran 1336(1920), Nr. 540/2840.Bkz. EK. IV

${ }^{113}$ Alemdar, 13 Haziran 1336(1920), Nr. 540/2840.
} 
Paşa ve onun gibi düşünen ülke ve millet düşmanlarının, Millî Mücadele aleyhindeki faaliyetleri her geçen gün artmaya ve tehlikeli olmaya başlamıştı. Kuva-yı Milliyeci oldukları için askerî komutanlar görevlerinden alınıyor, haklarında tutuklama kararları çıkartılıyor ve hatta meslekten uzaklaştırılıyorlardı. Yine memleketin idealist ve vatansever mülkî idarecileri basit gerekçelerle görevlerinden alınıyorlardı.

Bütün bunların yanında İngilizlerin istediği şekilde çalışmayı, onlara taahhüt etmiş olan Damat Ferit Paşa ve kurduğu hükûmetler, Türk halkının vatan mücadelesine verdiği desteği ortadan kaldırmak, bu mücadelenin ileri gelenlerine duyulan güven ve bağlılığı zayıflatmaya yönelik "Beyannâmeler ve Fetvalar" çıkartıyorlardı. Halkın dini duyguları istismar ediliyor, her yanda çıkartılan isyanlarla ülkeyi bir baştan bir başa kardeş kavgasına sürüklüyorlardı.

Yunanlılara karşı büyük fedakarlık ve yokluklar içerisinde "var olma ya da yok olma" mücadelesinin verildiği bu günlerde İstanbul'daki Millî Mücadele aleyhtarlığı ile ön plana çıkmış bazı şahsiyetlere yönelik bir suikastın planlanmış olması bir zaruretin sonucu olarak düşünülebilir. Damat Ferit Paşa, Ali Kemal, Sait Molla gibi ülke ve millet düşmanlıkları "vatan hainliği" noktasını da aşmış olan bu kişilerin bertaraf edilmesiyle, onlar gibi düşünen Millî Mücadele aleyhtarlarına bir ibret olacak, gözdağı verilecekti.

Ancak girişilen bu suikast girişiminin, ifşa olunarak etkisiz kalması, haklarında suikast yapılacak bu kişilerce, Millî Mücadele aleyhinde kamuoyu yaratmak için bir fırsat olarak görülmüştür. Millî Mücadele aleyhtarı Alemdar ve Peyam-ı Sabah gibi gazeteler konuyu günlerce ilk sayfalarına taşımışlar, sadece suikast girişiminden dolayı yakalanan ve yargılanan kişileri değil, bütün Millî Mücadele hareketini hedef almışlardı. Bu olaya Mustafa Kemal Paşa başta olmak üzere millî teşkilâtın ileri gelenleri bulaştırılmak istenmişti.

Bursa'daki Kuva-y1 Milliye ileri gelenlerince planlanan bu suikast girişimi şayet başarılı olmuş olsaydı, olayların seyri değişir miydi? Bunu bilemeyiz. Ancak bu şahısların sonraki aylar ve yıllarda Millî Mücadele'ye karşı giriştikleri haince teşebbüsler elbette ki söz konusu olmayacaktı. Delibaşı Mehmetlerin, Çapanoğullarının isyanları belki de çıkmayacaktı. Ülkemiz aylarca dahili karışıklıklar içerisinde çalkalanmayacak, büyük ölçüde sağlanmış millî birlik ve beraberlik zedelenmeyecekti. Millî güçlerin bütün mesaisi Yunan işgallerine ve diğer şer odaklarına yönelecek, belki de ülkemizin kurtuluşu, daha kısa sürede sağlanacaktı.

Suikastın baş tetikçisi olarak belirlenen Dramalı Rıza Beyin, "para meselesinden" dolayı, suikastı gerçekleştireceği arkadaşlarıyla anlaşmazlığa düştüğü ve suikastı ihbar ettiği şeklinde, gazetelerde çıkan haberler ve Divan-1 Harbin gerekçeli kararında yer alan ifadeler ne kadar sağlıklıdır 
bilemiyoruz. Ancak, Dramalı Rıza Beye yönelik yaptığımız araştırmadan ${ }^{114}$ Dramalı Rıza Beyin böyle bir yapıda kişi olmadığı kanaatine ulaşmış bulunuyoruz. Bu çalışmamızda da belirttiğimiz gibi, aslında ortada bir ihbar da yoktur. İstanbul Polis Müdürlügüü, suikast girişimi konusunda günlerce, belki de aylarca önce bilgi sahibi olmuştur. Dramalı Rıza Beyin ifşaatı suikasttan önce değil, Polis Müdürlüğü'ndeki sorgulanması esnasında işkence ve tazyik altında olduğunu ve "İstanbul'daki Millî Mücadele yanlısı kişilerin isimlerinin bulunduğu" bir listeyi verdiğini söylemek daha akla yakın gelmektedir. Çünkü kendisine affedileceği vaat edilmiş, o da son ana kadar böyle bir af beklentisi içinde olmuştur.

Suikast olayı, İstanbul'da gizli olarak kurulan ve Millî Mücadele'ye büyük hizmetleri olan Karakol Cemiyeti'ni de derinden sarsmıştır. Bu cemiyetin bir çok mensubu yakalanmış, bazıları doğrudan, bazıları da dolaylı olarak suikast girişimi ile ilişkilendirilerek cezalandırılmışlardır. Karakol Cemiyeti'nin bazı üyeleri ise, suikast davasının dışında ayrıca yargılanmışlar ve bu yargılama süreci aylarca sürmüştür. Nihayet Tevfik Paşanın son Hükûmeti döneminde "Kuva-yı Milliye'ye yardım ve hizmet etmek" gibi suçlardan Divan-1 Harb-i Örfi'lerde yargılanmakta olanların tamamı hakkındaki davalar, Harbiye Nezâreti'nce alınan bir kararla lağvedilmişti. ${ }^{115}$

Nemrut Mustafa Paşa Divan-1 Harb-i Örfisi'nde görülen suikast davasının adil bir şekilde yapıldığını söylemek mümkün değildir. Çünkü o günlerde bu mahkeme "Kuva-yı Milliye ile alakadar" oldukları gerekçesiyle bir çok sivil

114 “(Nemrut) Mustafa Paşa Divan-1 Harbi'nde Yargılanarak İdam Edilen Bir Kuva-yı Milliyeci: Dramalı Rıza Bey ve Millî Mücadele'deki Hizmetleri” başlıklı bu çalışmamız yayınlanması amacıyla Atatürk Araştırma Merkezi Dergisi Yayın Kuruluna gönderilmiştir. (O.A.)

${ }^{115}$ Kuva-yı Milliye ile ilgili olmalarından dolayı sanık durumuna düşerek Divan-1 Harb-i Örfi'lere verilerek yargılananlar hakkında 16 Nisan 1921 tarihinde Harbiye Nezâreti'nin bir tezkeresi ile bütün davalar lağvedilmişti. Bu karara gerekçe olarak ta "Kuvayi Milliye'nin vatanın savunulması için teşekkül etmiş bir kuvvet olduğuna şüphe yoktur. Düşman tecavüzlerine karşı vatan ve milletin namusunu kahramanca savunma ve koruma ile meşgul bulunduğu böyle bir zamanda yalnız Kuvayi Milliye ile ilgilerinden dolayı sanık tutulmuş olan bu kimselerin takdir ve alkışlanmaya değer vatanseverliklerinin suç sayılarak sanıklık altında bulunmaları ve bunu sonunda yargılamalarının yapılarak aleyhlerinde bir hüküm çıkarılması adaletle bağdaşmayacağından bu gibi davaların tümünün birden lağvedilerek kovuşturma ve hükümden düşürecek bir karar alınması hakkında gereken teşebbüslerin yapılması bildirilmiştir" denilmekteydi. Hamdi Atamer, "Milli Mücadeleye Katılanlar Hakkında Askeri Yargıtay Kararı”, Belgelerle Türk Tarihi Dergisi, Sayı: 3, İstanbul 1967, s.5-6, Belge No:3; Ayrıca bkz. Metin Ayışı̆̆ı, Mareşal Ahmet İzzet Paşa (Askerî ve Siyasî Hayatt), TTK Basımevi, Ankara 1997, s. 239. Konuyla ilgili bir değerlendirmeler için de bkz. Yücel Özkaya, "Kuvayı Milliye" Atatürk Kültür, Dil ve Tarih Yüksek Kurumu Atatürk Araştırma Merkezi Dergisi, Sayı:24, (Temmuz 1992), Ankara 1992, s.; Metin Ayışı̆̆ı, "Son Osmanlı Hükûmeti ile Ankara Hükûmeti Arasındaki Münasebetler(21 Ekim 1920- 4 Kasım 1922), Toplumsal Tarih, C.1, Say1:6 (8haziran 1994, İstanbul, s.12. 
ve askerî şahsiyet hakkında idam cezaları vermiştir ${ }^{116}$. Bunların büyük bir kısmı kin ve garaz yüklü, haksız kararlar olmuştur. Nitekim suikast davasından yargılanarak idam edilen Mehmet Ali Bey temyizen suçsuz bulunmuştu. DHÖ'nün kararları sonucu kesindi ve temyiz edilemiyordu. Edilebilseydi bu haklarını kullanırlardı. Bunun üzerine Mehmet Ali Bey ile Bahriye Yüzbaşısı Halil İbrahim Beyin geride kalan eşlerine maaş bağlanmıştı" ${ }^{117}$. Diğer taraftan Türkiye Büyük Millet Meclisi de "Millî Mücadele uğrunda şehit düşen ya da hayatını kaybeden" bir çok subay ve asker ailelerine yaptığı gibi Bahriye Yüzbaşısı Halil İbrahim Bey ile Tevfik Sükûti Beyin ailelerine"hidematı vataniye tertibinden" maaş bağlamıştı ${ }^{118}$.

\section{KAYNAKLAR}

\section{a) Arșivler}

Başbakanlık Osmanl Arşivi, Dosya Usulü İadeler Tasnifi.

Ankara Üniversitesi Türk Inkılâp Tarihi Enstitüsü Arşivi(TITE)

\section{b) Resmi Yayınlar}

Türkiye Büyük Millet Meclisi Zabit Ceridesi

c) Gazeteler

Alemdar,

Peyam-l sabah,

Takvim-i Vekâyi,

${ }^{116}$ Bu Divanı Harbi Örfinin, Mustafa Kemal Paşa ve arkadaşlarına olan düşmanca tutumundan, İstanbul'da bulunan Kuvayı Milliye yanlısı ve bu teşkilâta destek veren asker ve sivil bürokratlar da nasiplerini almıştır. Nitekim teğmenden generallere, memurdan emniyet amirine kadar pek çok devlet adamı, "halkı zehirledikleri, Kuva-yı Bagiyye'yi destekledikleri gerekçesi ile, idam talebi ile yargılanmak üzere İstanbul Birinci Divan-1 Harbi Örfisine gönderilmişlerdir. Bunun yanı sıra, Kuvayı Milliye yanlısı yüzlerce subay,gıyaplarında idama mahkum edildiği gibi, bir yolunu bulup da Anadolu'ya geçenler askerlikten ihraç edilmişlerdir. Bu değerlendirme için bkz. Metin Ayışı̆̆ı, "Bir Askeri Mahkeme: İstanbul Birinci Divânı Harbi Örfisi”, Yedinci Askeri Tarih Semineri Bildirileri I, Genelkurmay Başkanlığı Yay., Ankara 2000, s.386.

${ }^{117}$ Erdem, agt., s. 187.

${ }^{118}$ Bahriye Yüzbaşısı Halil İbrahim Bey ile ilgili Heyet-i Vekile tarafından verilen kanun teklifinde şöyle deniliyordu: "Şehit Çarkçı Yüzbaşı Halil Efendi ailesine hidematı vataniye tertibinden maaş tahsisine dair Heyeti Vekileden mevrud Lâyihai kanuniye......" Bkz. Türkiye Bïyük Millet Meclisi Zabut Ceridesi, Devre I, İçtima Senesi 3, Cilt:25, Ankara 1960, s.406. Cebelibereket mebusu İhsan Beyin, şehit Tevfik Sukûti Beyin valide ve hemşiresine bin kuruş maaş tahsisine dair kanun teklifi TBMM'sinde görüşülmüştü. Meclis reisi bu konuda “ Tevfik Sukûti merhumun ailesine hidematı vataniye tertibinden maaş tahsisine dair olan bu teklifin bu babta icabeden mâlumatın tahkîk ve inbası zımmında Maliye Vekaletine havalesi lüzumuna" demiştir. Bkz. TBMM ZC, Devre I, İçtima Senesi 3, Cilt:26, Ankara 1960, s.7. Ayrica bkz. Erdem, agm., s.188. 
Vakit

d) Kitaplar

AtAtüRK, M. Kemal, Nutuk, C. 1(1919-1920), Yay. Haz. Zeynep Korkmaz, Başbakanlık Basımevi, Ankara 1984.

, Nutuk, C. III (1919-1927) Belgeler, Yay. Haz. İsmet Gönülal, Başbakanlık Basımevi, Ankara 1984.

AYDIN, Mesut, Millî Mücadele Döneminde TBMM Hükümeti Tarafından Istanbul'da Kurulan Gizli Gruplar ve Faâliyetleri, Boğaziçi Yay., İstanbul 1992.

AYIŞIĞI, Metin, Mareşal Ahmet İzzet Paşa (Askerî ve Siyasî Hayatı), TTK Basımevi, Ankara 1997.

Balıkesir ve Alaşehir Kongreleri ve Hacim Muhittin Çarıklı'nın Kuvayı Milliye Hatıraları 1919-1920, Yay. Haz. Şerafettin Turan, Türk İnkılâp Tarihi Enstitüsü Yay., Ankara 1967.

BİLGİ, Necdet, Ermeni Tehciri ve Boğazlıyan Kaymakamı Mehmet Kemal Beyin Yargılanması, Köksav Yay., Ankara 1999.

CEBESOY, Ali Fuat, Millî Mücadele Hatıraları, Temel Yay., İstanbul 2000.

DÖNMEZ, Cengiz, Millı̂ Mücadele'ye Karşı Bir Cemiyet:Ingiliz Muhibleri Cemiyeti, Atatürk Araştırma Merkezi Yay. Ankara 1999.

ERTÜRK, Hüsamettin, Íki Devrin Perde Arkası, Yay. Haz. Samih Nafiz Tansu, Sebil Yay., İstanbul 1964.

, Millî Mücadele Senelerinde Teșkilât-ı Mahsusa, Daktilo Metin (Yay. Haz. Tevfik Apay), Genelkurmay ATASE Kütüphanesi, Ankara 1985.

EZHERLİ, İhsan, Türkiye Büyük Millet Meclisi(1920-1998) ve Osmanlt Meclis- $i$ Mebusanı (1877-1920), 2. Baskı(Genişletilmiş), TBMM Kültür, Sanat ve Yayın. Kururlu Yay., Ankara 1978.

GÜVEN, Zühtü, Anzavur İsyanı-Kurtuluş Savaşı Hatıralarından Acı Bir Sayfa, Ankara 1965.

GÖRGÜlü, İsmet, On Yıllık Harbin Kadrosu 1912-1922(Balkan-Birinci Dünya ve Ístiklâl Harbi), TTK Basımevi, Ankara 1993.

HOŞGÖR, İsmail Aydın, Kurtuluş Savaşı'nda Biga, Biga 1970.

İĞDEMİR,Uluğ, Biga Ayaklanması ve Anzavur Olayları(Günlük Anılar), TTK Basımevi, Ankara 1989.

INAL, İbnülemin Mahmut Kemal, Son Sadrazamlar, C.4, 3.Baskı, Dergah Yay. 1982.

KARABEKİR,General, Cemal, Maçka Silâhhanesi Hatıraları (İstiklâl Harbi Kahramanlart), Yay. Haz. Aykut Kazancıgil, Nehir Yay., İstanbul 1991.

KoZAnOĞLu, Zeynel, Hamdi Bey ve Akbaş Baskını, Ankara 1970. 
KuTAY, Cemal, Çerkes Ethem Hadisesi(Kendi Hatıralarıyla), Tarih Kütüphanesi Yay., İstanbul 1955.

ÖZALP, Kazım, Millı̂ Mücadele I (1919-1922), 2.Basım, Türk Tarih Kurumu Basımevi, Ankara 1985.

ÖZSOY, Osman, Gazetecinin İnfazı, Timaş Yay. İstanbul 1997.

SANAY, Recai, Türk Casusu İngiliz Kemal İstiklâl Harbinde, Nebioğlu Yay. İstanbul 1958.

TEKTAŞ, Nazım Sadrâzamlar-Osmanlı'da İkinci Adam Saltanatı, Çatı Kitapları, İstanbul 2002.

TEPEYRAN, Ebubekir Hazım, Zalimane Bir İdam Hükmü, Milli Mecmua Basımevi, İstanbul 1946.

TeVEToĞLU, Fethi, Millî Mücadele Yıllarındaki Kuruluşlar, TTK Basımevi, Ankara 1988.

TOPUZLU, Opr. Dr.Cemil (Paşa), İstanbul Eski Şehremini, Ístibdat-MeşrutiyetCumhuriyet Devirlerinde 80 Yıllık Hatıralarım, Haz. Cemalettin Topuzlu, 4. Bs., İstanbul 2002

TUNAYA, Tarık Zafer, Türkiye'de Siyasi Partiler 1859-1952, II. Baskı (Tıpkı Basım), Arba Yay., İstanbul 1952.

UnAt, Faik Reşit, Hicrî Tarihleri Milâdî Tarihe Çevirme Kılavuzu, 4.Basım, TTK Basımevi, Ankara ${ }^{1}$

e) Makaleler

AKÇAM, Taner, "Divan-1 Harb-i Örfi'lerin Kurulması-İstanbul Yargılamaları-" Tarih ve Toplum, Sayı: 13,(Mayıs 1995), s.47-52.

AYIȘIĞI, Metin, "Son Osmanlı Hükûmeti ile Ankara Hükûmeti Arasındaki Münasebetler(21 Ekim 1920-4 Kasım 1922), Toplumsal Tarih, C.1, Sayı:6 (8haziran 1994, İstanbul, s.12-18.

, "Bir Askeri Mahkeme: İstanbul Birinci Divânı Harbi Örfisi", Yedinci Askeri Tarih Semineri Bildirileri I, Genelkurmay Başkanlığı Yay., Ankara 2000, s.381-390.

ATAMER, Hamdi, "Milli Mücadeleye Katılanlar Hakkında Askeri Yargıtay Kararı”, Belgelerle Türk Tarihi Dergisi, Sayı:3, İstanbul 1967, s.3-8.

ErLer, M. Yavuz, "Damat Ferit'e Suikast” Atatürk Üniversitesi, Atatürk İlkeleri ve İnkılâp Tarihi Enstitüsü Atatürk Dergisi "Doç. Dr. Günay Çağlar Özel Sayısı", C.III, Sayı:2, (Temmuz 2002), s.107-119.

GöZTEPE, Tarık Mümtaz, "Nemrut Mustafa'nın Astığı Kuvayı Milliyeciler”, Dün ve Bugün, Y1l:1, C.1, S.12,(20 Ocak 1956), s.6-7 ve 27

, "Yaşasın İttihad-1 Terakki", Dün ve Bugün, Sayı:13, Y1l:1, Cilt:1, (27 Ocak 1956), s.20 ve 27.

ÖZKAYA, Yücel, "Kuvayı Milliye” Atatürk Kültür, Dil ve Tarih Yüksek Kurumu Atatïrk Araştırma Merkezi Dergisi, Sayı: 24, (Temmuz 1992), Ankara 1992 
SERTOĞLU, Midhat, "Millî Mücadeleye Yardım Ettikleri İçin Cezalandırılmak İstenenlere Dair Yayınlanmamış Belgeler, Hayat Tarih Mecmuası, Yıl:14, C.1, Sayı:2, (1 Şubat 1978), İstanbul, s.47-49.

f) Tezler

Erdem, Ş. Can, Sadrazam Damat Ferit Paşa, Marmara Üniversitesi Sosyal Bilimler Enstitüsü, Basılmamış Doktora Tezi, İstanbul 2002. 
DAMAT FERIT PAŞAYA KARŞI DÜZENLENEN BIR SUIKAST GIRIŞIMI.... 113

EKLER

-iteres

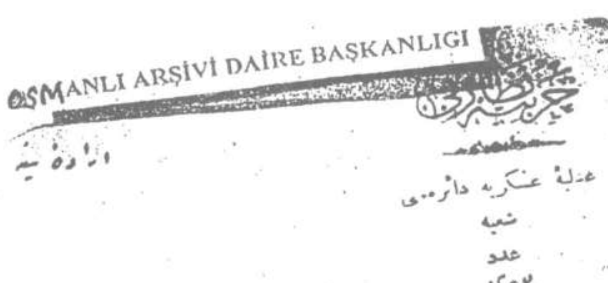

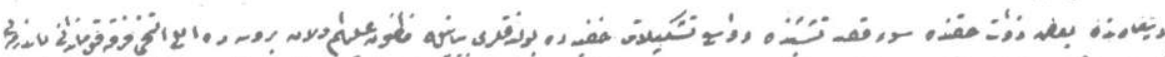

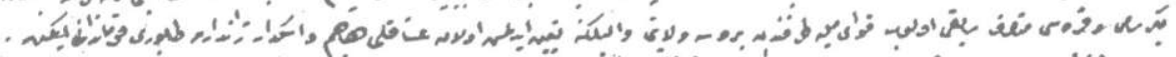

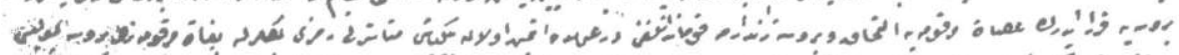

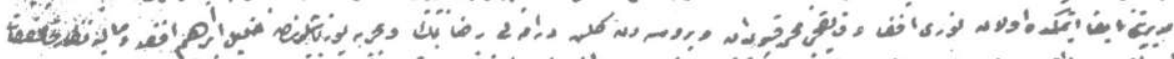
":

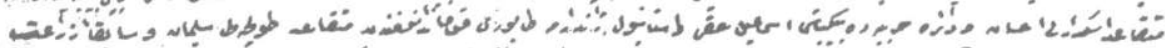

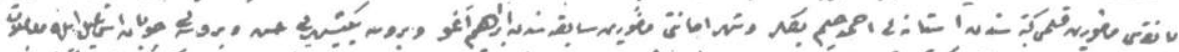

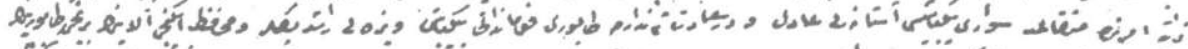

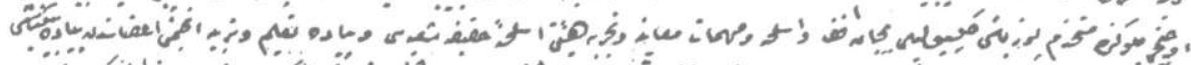

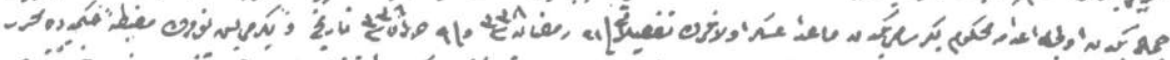

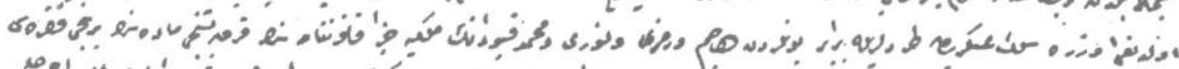

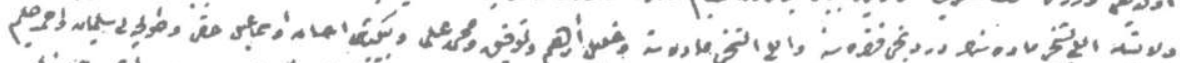

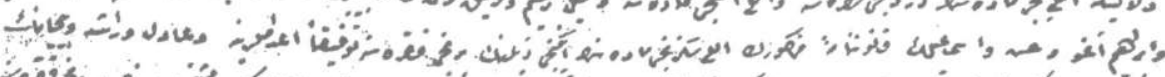

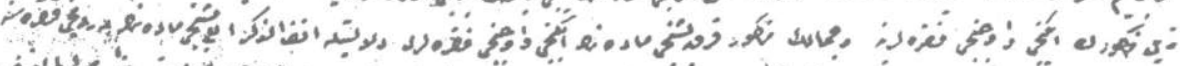

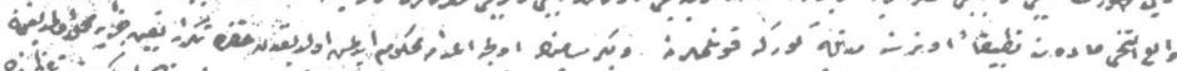

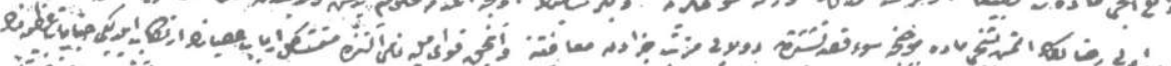

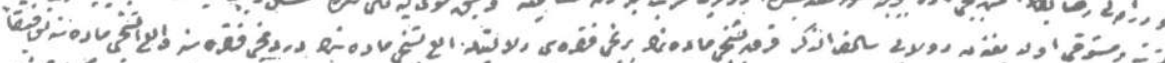

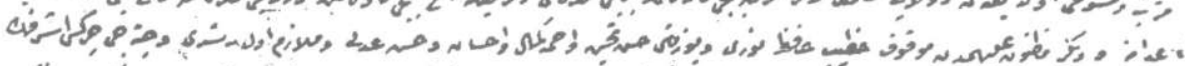

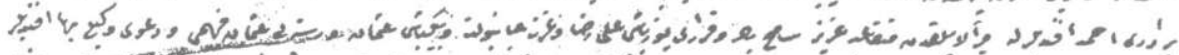

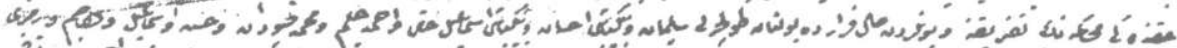

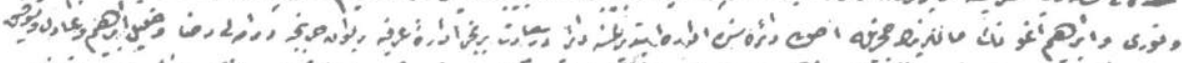

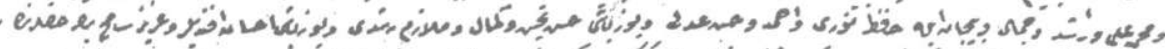

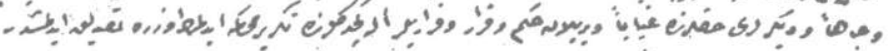

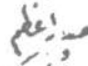

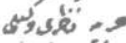

पivivis

EK-I Suikastçıların İdami ile IIIgili İrade, I Seniyye

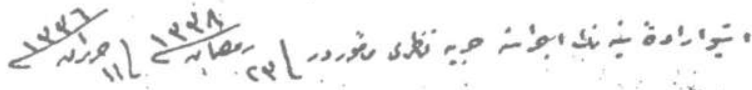




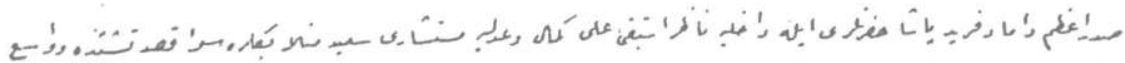

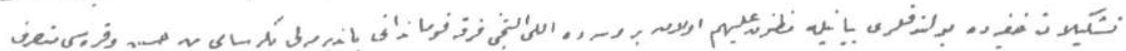

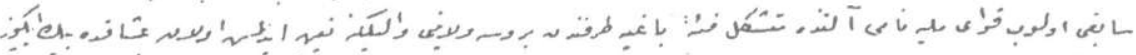

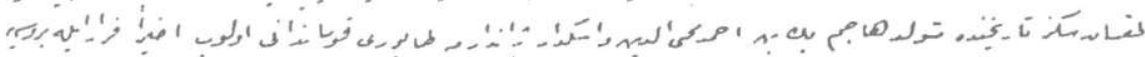

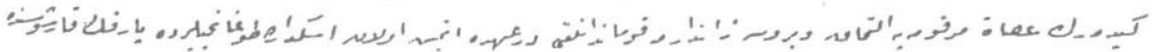

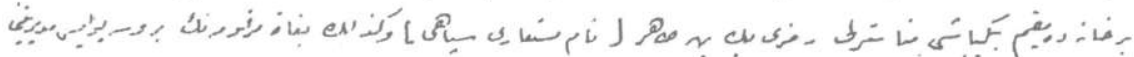

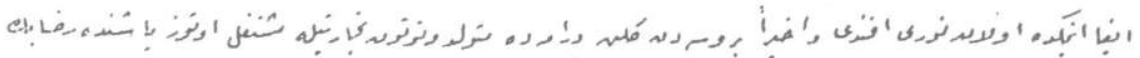

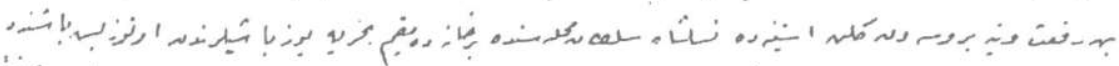

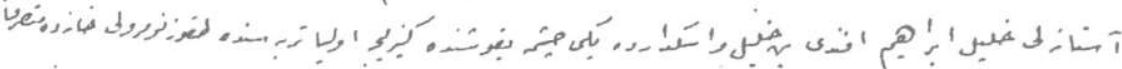

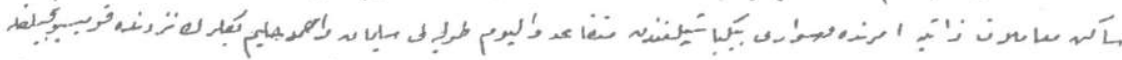

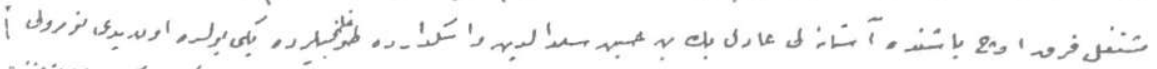

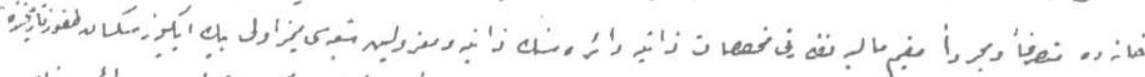

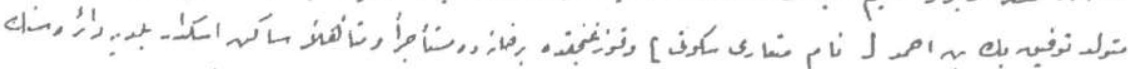

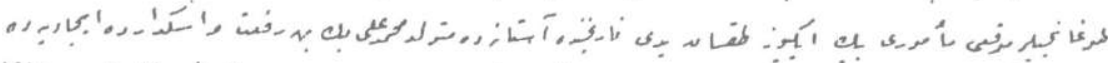

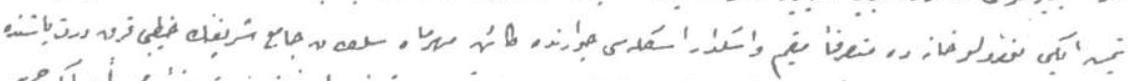

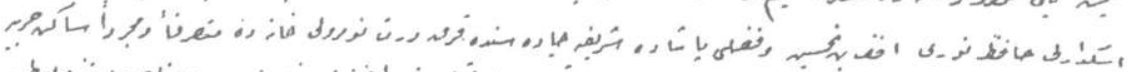

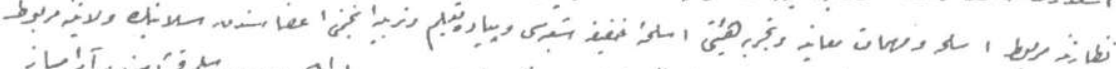

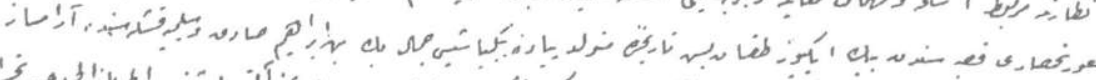

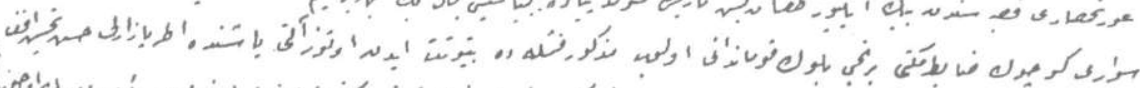

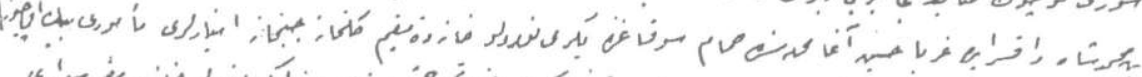

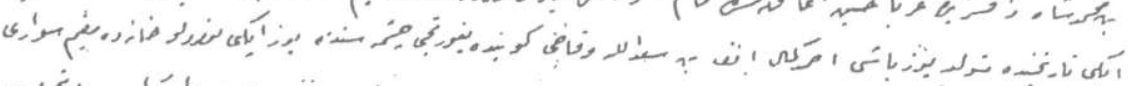

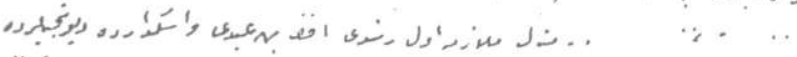

EK-II Suikastçileri Yargılayan Divan-1 Harb-i Özü'nün Mazbata-i Hükmiyye'sinin (Gerekçeli Karar) Birinci Sayfası 


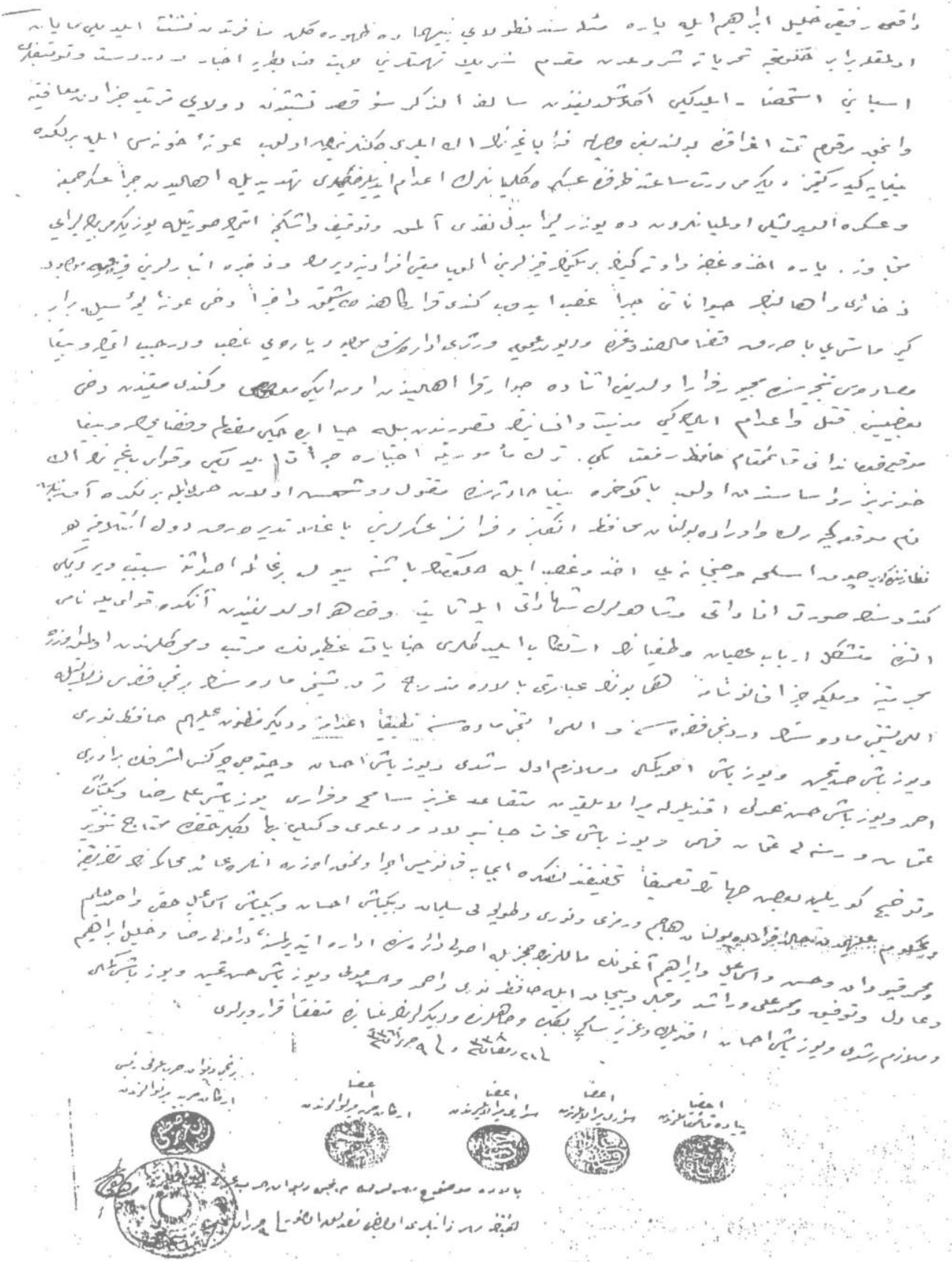

EK-III

Suikastçileri Yargılayan Divan-1 Harb-i Özü'nün Mazbata-i Hükmiyye'sinin (Gerekçeli Karar) Son Sayfası 


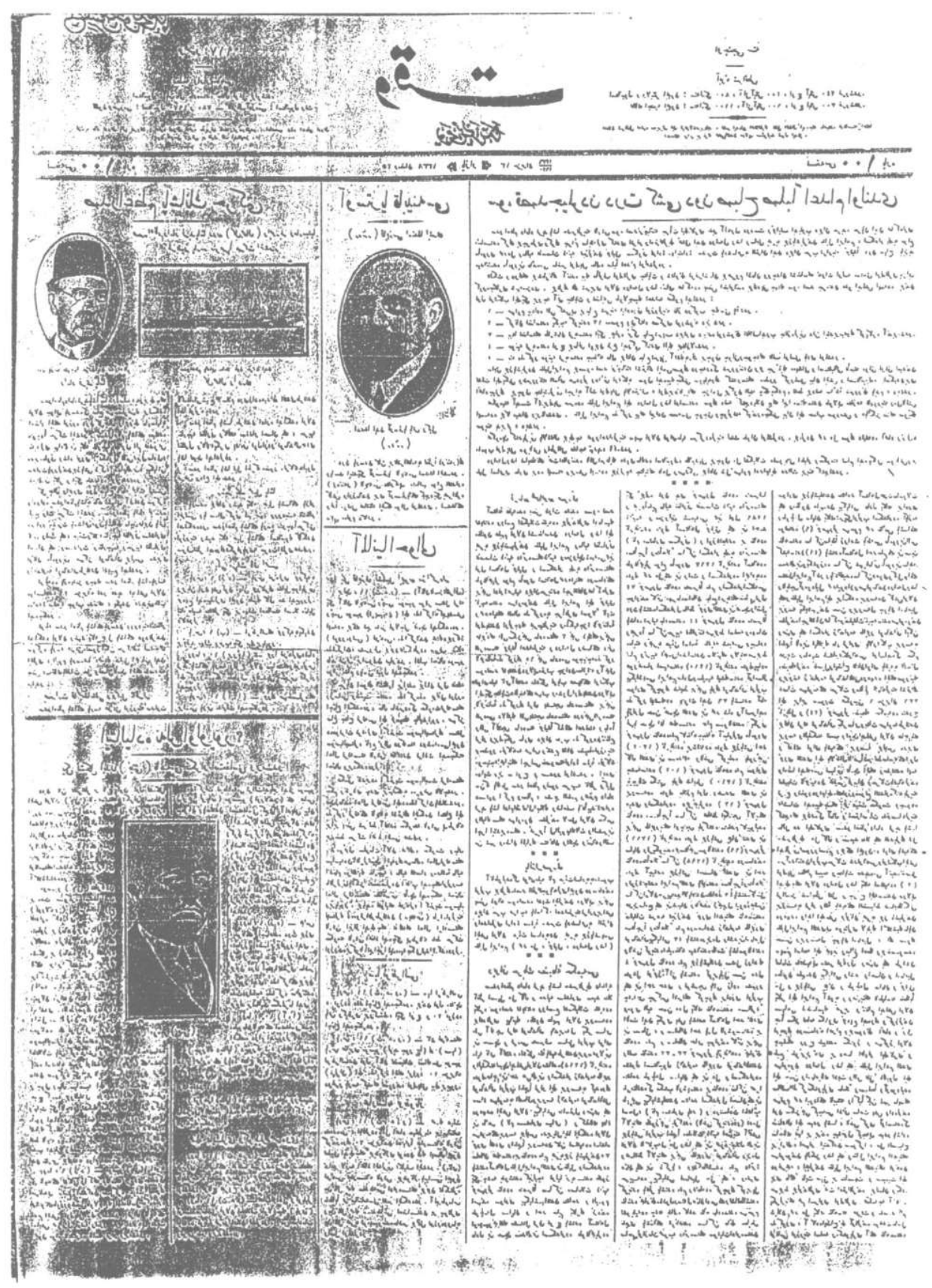

EK-IV

13 Haziran 1336 (1920) Tarihli Vakit Gazetesi'nde Suikastçilerin İdamı İle İlgili Haber 


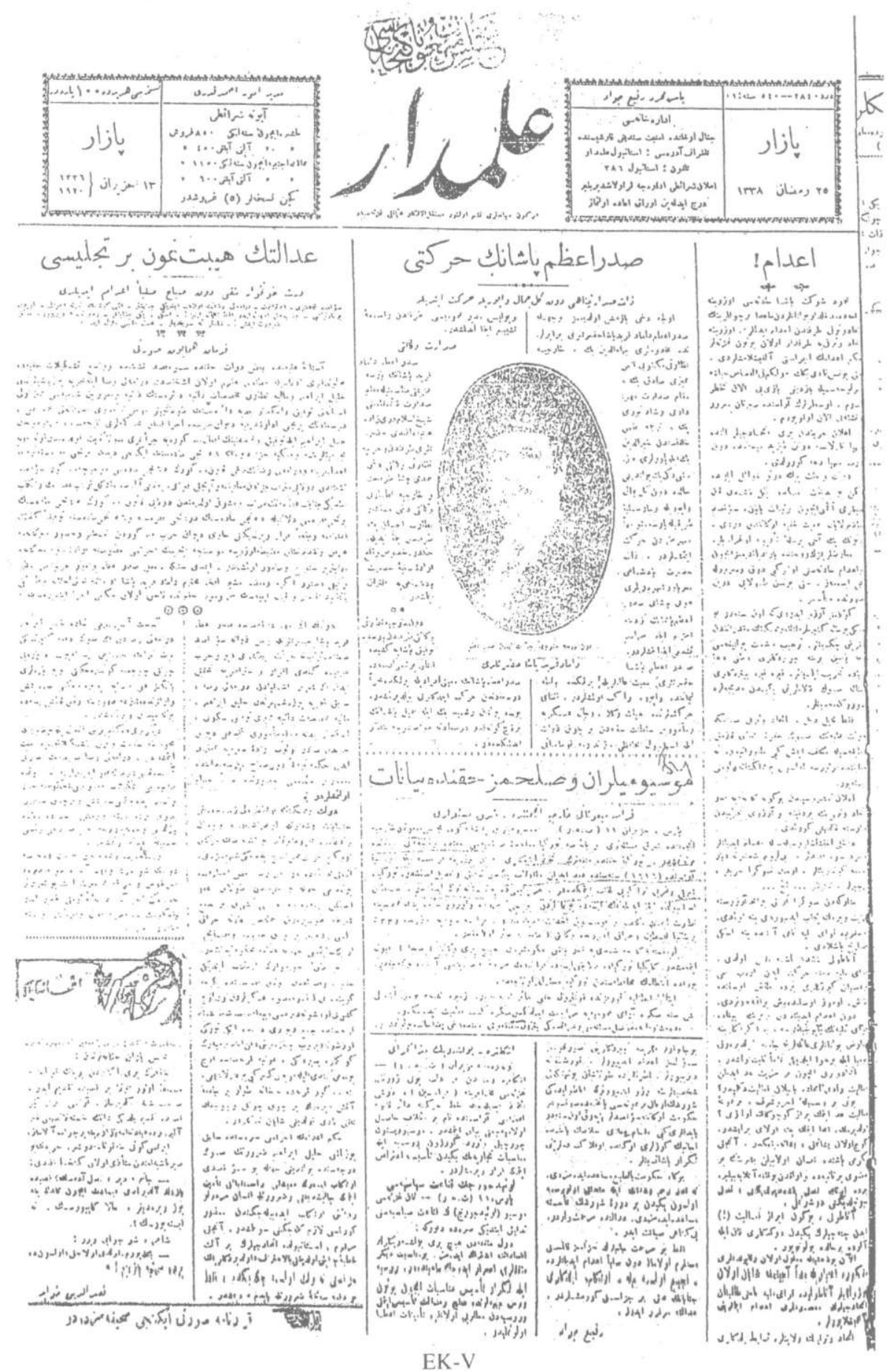

13 Haziran 1336 (1920) Tarihli Alemdar Gazetesi'nde Suikastçilerin İdamı İle İlgili Haber 